Zagłada Żydów. Studia i Materiały, R. 2020, nr 16

ISSN (print): 1895-247X; eISSN: 2657-3571

DOI: https://doi.org/10.32927/ZZSiM.668

\title{
Aleksandra Kasznik-Christian
}

https://orcid.org/0000-0002-7005-6435

akasznik@poczta.onet.pl

\section{Sprawa Marty Puretz, domniemanej agentki Gestapo z krakowskiego getta}

\begin{abstract}
Streszczenie
Martę Puretz literatura naukowa obsadza w charakterze konfidentki Gestapo. Tymczasem przeczy temu konsultacja obfitej dokumentacji źródłowej z Archives Nationales w Paryżu. Nieprzypadkowo zatem autorka używa określenia „domniemana agentka”. Artykuł stanowi udokumentowane odtworzenie losów Marty Puretz w Polsce, na Węgrzech i we Francji, także tych powojennych, bo tylko takie ujęcie pozwoli zrewidować utarte sądy. Przybliża środowisko krakowskiej zasymilowanej inteligencji żydowskiej, które Puretz ukształtowało, jej pobyt w getcie i walkę o przetrwanie, ucieczkę z obozu płaszowskiego i szczęście posiadania po aryjskiej stronie dwóch oddanych kobiet - niani i byłej służącej - na które zawsze mogła liczyć. Przed ucieczką na Węgry na kilka miesięcy znalazła oparcie w gronie polskich znajomych, którzy ją przechowywali. Węgry nie były dla niej wybawieniem, stały się raczej potrzaskiem. Nieszczęsnym epizodem była jej czasowa zależność od polskiego Żyda, niejakiego Fabera, który później dwukrotnie oskarżał ją o współpracę z Gestapo. Na Węgrzech związała się z Charles’em Herozem, pracownikiem attaszatu francuskiego w Budapeszcie. Ukrywając się u niego, pomagała mu w podziemnej działalności antyniemieckiej. Pobrali się w 1945 r., po zdobyciu Budapesztu przez Armię Czerwoną. Oskarżona przez Fabera o współpracę z Niemcami, była sądzona przez węgierski Trybunał Ludowy, który z braku dowodów ją uniewinnił. Po wyjeździe Marty Puretz do Francji strona polska wpisała ją na listę zbrodniarzy wojennych, do czego walnie przyczyniły się oskarżenia Fabera, i przez kilka lat domagała się bezskutecznie jej ekstradycji.
\end{abstract}

\section{Słowa kluczowe}

kolaboracja, konfidenci, Marta Puretz, Aleksander Förster, Stanisław vel Marian Faber, Charles Heroz, getto krakowskie, Legacja Francuska w Budapeszcie, polscy Żydzi na Węgrzech, ekstradycja do Polski

\footnotetext{
Abstract

Reference literature casts Marta Puretz in a role of a Gestapo informer. However, a search query conducted in the large collection of documents stored at the Archives Nationales in Paris contradicts that. It is not by accident that Puretz is called a 'purported agent'. This article constitutes a typical, meticulously documented reconstruction of her life - in Poland, in Hungary, and also in France after the war, for only such an outlook can facilitate a revision of existing opinions. The author describes the milieu of the assimilated Cracow Jewish intelligentsia which shaped her; her stay in the ghetto and fight for survival; her escape from the Płaszów camp and the fortunate circumstance of her having two women on the 'Aryan' side - her nanny and
} 
former maid - who she could always count on. Before fleeing to Hungary she received help for several months from a group of her Polish friends, who sheltered her. Hungary was not a salvation to her. It was more of a trap. An unfortunate episode was her temporary dependence on a Polish Jew, a man named Faber, who later accused her twice of cooperation with the Gestapo. In Hungary she became romantically involved with Charles Heroz, an employee of the French attaché's office in Budapest. Hiding at his place, she helped him conduct his underground anti-German activity. The couple got married in 1945 after the Red Army had captured Budapest. Accused by Faber of collaboration with the Germans, she was tried by the Hungarian People's Tribunal, which acquitted her for lack of evidence. After Marta Puretz's departure to France the Polish side unsuccessfully demanded her extradition for several years after putting her on a list of war criminals, to which significantly contributed Faber's accusations.

\section{Key words}

collaboration, informers, Marta Puretz, Aleksander Förster, Stanisław a.k.a. Marian Faber, Charles Heroz, Cracow ghetto, French legacy in Budapest, Polish Jews in Hungary, extradition to Poland

Martę Puretz ${ }^{1}$ literatura naukowa ${ }^{2}$ obsadza w roli konfidentki Gestapo. Została zaocznie oskarżona przez Specjalny Sąd Karny w Krakowie na podstawie zebranych po 1945 r. zeznań trzech osób. Przy czym doniesienia jednego z głównych świadków, a zarazem pomysłodawcy jej ścigania, okazują się całkowicie

${ }^{1}$ Historia Marii Puretz jest odtworzona na podstawie informacji zawartych w Archives Nationales w Paryżu (dalej AN) oraz archiwów Instytutu Pamięci Narodowej w Krakowie (dalej AIPN Kr) i w Warszawie (AIPN). Dane personalne Puretzów czerpałam z zamieszczonych online formularzy rejestracyjnych Żydów (USHMM, Kraków, Poland, ID Card Applications for Jews During WWII, 1940-1941). Fotografia Marty Puretz pochodzi z archiwum IPN (AIPN Kr, 010/6637), a kserokopia tej fotografii znajduje się w Archives Nationales (AN, 19910593/7, Nota ambasady polskiej do francuskiego ministerstwa spraw zagranicznych, 10 III 1948 r.).

${ }^{2}$ Zob. np. Witold Mędykowski, Przeciw swoim. Wzorce kolaboracji żydowskiej w Krakowie i okolicy, „Zagłada Żydów. Studia i Materiały” 2006, nr 2, s. 202-220 (online: www.ceeol.com); Martyna Grądzka-Rejak, Kobieta żydowska w okupowanym Krakowie (1939-1945), Kraków: Wysoki Zamek, 2016; Alicja Jarkowska-Natkaniec, Wymuszona współpraca czy zdrada. Wokót przypadków kolaboracji Żydów w okupowanym Krakowie, Kraków: Universitas, 2018. Alicja Jarkowska-Natkaniec pisze, iż w kontekście kolaboracji nazwisko Marty Puretz było podawane w kilku powojennych publikacjach: $W$ trzeciq rocznicę zagłady getta $w$ Krakowie, red. Michał M. Borwicz, Nella Rost, Józef Wulf, Kraków: Centralny Komitet Żydów, 1946, s. 47 (reprint: Austeria, 2013); Józef Bau, Czas zbezczeszczenia. Wspomnienia z czasów drugiej wojny światowej, Tel Awiw: Hamena Anea, 1990 s. 87; Józef Bratko, Gestapowcy. Kontrwywiad - konfidenci konspiratorzy, Kraków: Krajowa Agencja Wydawnicza, 1990. Informacje te powielano później w naukowych i popularnonaukowych publikacjach dotyczących okupowanego Krakowa i getta krakowskiego. Jarkowska-Natkaniec ustosunkowuje się do wartości wskazywanych publikacji. Poważnym mankamentem pracy Bratki jest skromna liczba wykorzystanych źródeł oraz brak proweniencji przytaczanych dokumentów. Zdecydowanie więcej wnosi artykuł Mędykowskiego, który przedstawia sylwetki prominentnych konfidentów z Krakowa i Bochni. Autorka sądzi - i ja podzielam jej pogląd - iż celem Mędykowskiego było zasygnalizowanie problemu kolaboracji w dystrykcie krakowskim, co wymaga dalszej kwerendy i studiów. 
niewiarygodne. Stanowią bezmiar kłamstw, o czym świadczy obfita dokumentacja źródłowa przechowywana w Archives Nationales w Paryżu ${ }^{3}$, niebrana dotychczas pod uwagę przez historyków. Dlatego wracam do tego tematu.

Problem ten został podjęty stosunkowo niedawno. Wyczerpująco sprawę kolaboracji Żydów w Krakowie omówiła Alicja Jarkowska-Natkaniec. Prócz źródeł drukowanych i prasy podziemnej wykorzystała archiwalne materiały śledcze i procesowe. Dzięki krytycznej metodzie badawczej brała za pewnik tylko te informacje, które znajdowały potwierdzenie w kilku odrębnych źródłach. Dzięki temu podała $\mathrm{w}$ wątpliwość m.in. utarte przekonanie, że Marta Puretz była powiązana z tzw. siatką Diamanta, uznawaną za grupę agenturalną działającą przeciwko polskiemu podziemiu. Jarkowska-Natkaniec uważała, że funkcjonowanie tej siatki w okupowanym Krakowie trudno prześledzić. Mimo przesłuchania kilku świadków nie odnaleziono dowodów potwierdzających współpracę Puretz z władzami okupanta. Nie wzbudzała zainteresowania żydowskiego podziemia ani mieszkańców getta. Niemniej Jarkowska-Natkaniec dzięki dostępnym informacjom uznała Martę Puretz za osobę, która prowadziła działalność konfidencką na własną rękę.

Archiwalia francuskie stanowią nie tyle uzupełnienie materiałów wykorzystanych przez Jarkowską-Natkaniec, ile całkowicie przewartościowują dotychczasowe ustalenia. W ich świetle Marta Puretz była młodą dziewczyną, którą zbiegi okoliczności doprowadziły w końcu do umieszczenia na liście zbrodniarzy wojennych. Rekonstrukcja wydarzeń, dokonana na podstawie wielostronnej dokumentacji z Archives Nationales, pozwala uwolnić Martę Puretz od fałszywych oskarżeń o współpracę z Gestapo. Nie dość, to główny oskarżyciel okazał się przez pewien czas informatorem Gestapo.

Opowieść o Marcie Puretz stanowi przyczynek - i sprostowanie - do historii żydowskich informatorów ${ }^{4}$. Wpisuje się $\mathrm{w}$ obszar mikrohistorii, tak silnie

${ }^{3}$ Zawdzięczam ją uprzejmości Simona Londnera, który dostarczył mi kserokopie dokumentów, za co mu w tym miejscu serdecznie dziękuję.

${ }^{4}$ Praktycznie w każdym kraju wyzwolonym spod okupacji natychmiast odbywały się procesy ludzi określanych jako kolaboranci. Nie ominęły one także Żydów - niektórzy zostali postawieni przed sądem przez władze, a inni byli sądzeni przez żydowskie sądy honorowe. W Polsce od 1944 r. rozliczeniami zbrodni wojennych zajmowały się głównie prokuratury specjalnych sądów karnych, sądów administracyjnych, sądów okręgowych i Naczelnego Trybunału Narodowego, a także Sąd Społeczny przy Centralnym Komitecie Żydów w Polsce (CKŻP). Przed polskim wymiarem sprawiedliwości pod zarzutem kolaboracji stanęło 44 Żydów. 30 otrzymało wyroki skazujące, w tym 10 karę śmierci. Decyzją sądu uniewinniono co najmniej kilkunastu Żydów, najwięcej przez SSK w Krakowie. Zarzuty zdrady usłyszeli przede wszystkim policjanci żydowscy z dystryktu krakowskiego, a także konfidenci żydowscy z tzw. siatki Diamanta (Jarkowska-Natkaniec, Wymuszona współpraca czy zdrada?..., s. 380).

Warto pamiętać, że żydowscy informatorzy wpisują się w szerszy kontekst współpracowników Gestapo w ogóle (V-Personen) i działań prowokacyjnych prowadzonych przez stronę niemiecką. Historycy podejmują obecnie badania w tym kierunku, o czym świadczy zróżnico- 
powiązanej z historią codzienności. Badania takie otwierają perspektywę na zrozumienie zjawisk i mechanizmów, które wykraczają poza lokalność, pojedyncze przypadki mogą się bowiem okazać kluczowe przy zarysowywaniu ogólniejszych zdarzeń, w tym kontekście dziejów żydowskich informatorów. W ten sposób mikrohistoria staje się doskonałą metodą badania i zrozumienia natury Zagłady z wielu perspektyw - jej ofiar, niemieckiej polityki i postaw polskiej społeczności ${ }^{5}$. Jednocześnie - co niebagatelne - przywraca pamięć o losach jednostkowych. W przypadku Marty Puretz analiza wycinka jej biografii z czasów okupacji oddaje desperacką i nieustającą walkę o przetrwanie. Przy czym najczęściej strategii przetrwania pomagał przypadek i łut szczęścia, które towarzyszyły pojedynczym decyzjom. Do historii Marty Puretz podchodzę z perspektywy feministycznej. Doświadczenia kobiet były inne aniżeli mężczyzn. To właśnie płeć pozostawała ważnym czynnikiem określającym to doświadczenie. Kobietom groziło dodatkowo zseksualizowane upokorzenie i przemoc ${ }^{6}$. Zdarzało się zatem, że młode kobiety same wykorzystywały atrakcyjność seksualną do zyskania ochrony ze strony mężczyzn, którzy mogli ją zapewnić. Uciekały się do flirtów czy nieformalnych związków.

wana literatura przedmiotu (Marek Jan Chodakiewicz, Agenci i bandy pozorowane na Lubelszczyźnie. Z dziejów okupacji niemieckiej w Janowskiem, „Radzyński Rocznik Humanistyczny” 2002, nr 2, s. 113-126; Tomasz Frydel, Powiat dębicki [w:] Dalej jest noc. Losy Żydów w wybranych powiatach okupowanej Polski, red. Barbara Engelking, Jan Grabowski, Warszawa: Stowarzyszenie Centrum Badań nad Zagładą Żydów, 2018, t. 2, s. 499-511; Dawid Golik, Prowokacja w walce $z$ „bandami”. Wybrane przykłady niemieckich akcji prowokacyjnych z terenu dystryktu krakowskiego GG, „Prace Historyczne” 2017, nr 144 (4), s. 691-711; Claire M. Hall, An Army of Spies? The Gestapo Spy Network 1933-45, „Journal of Contemporary History” 2009, t. 44, nr 2, s. 247-265; Claire M. Hubbard-Hall, "A Game of Cat-and-Mouse”. The Gestapo Spy Network in Tomaschow Mazowiecki, Poland 1939-45 [w:] War in a Twilight World: Partisan and AntiPartisan Warfare in Eastern Europe, 1939-45, red. Juliette Pattinson, Ben Shepherd, London: Palgrave Macmillan, 2010, s. 156-177; Doris Tausendfreund, Erzwungener Verrat jüdische „Greifer” im Dienste der Gestapo 1943-1945 (Documente, Tekste, Materialien), Berlin: Metropol, 2005). Chciałabym w tym miejscu serdecznie podziękować recenzentowi mego artykułu - jego uwagi i użyczone mi wskazówki bibliograficzne pozwoliły mi spojrzeć na opisywane zdarzenia z szerszej perspektywy.

${ }^{5}$ Dalej jest noc..., t. 1, s. 17.

${ }^{6}$ Egzemplifikacją tych zjawisk jest narracja Martyny Grądzkiej-Rejak w jej pracy Kobieta żydowska w okupowanym Krakowie..., nowatorskiej na gruncie polskiej historiografii. Rozdział czwarty tej publikacji traktuje m.in. o cielesności kobiet. Są w nim zawarte opisy traumatycznych przeżyć związanych z rewizjami osobistymi, podczas których dotykano niekiedy intymnych części ciała kobiet. Równie dojmujących przeżyć doświadczały dziewczęta, które od 14. roku życia poddawano zarządzonym przez okupanta badaniom antropologicznym, naruszającym ich intymność (Grądzka-Rejak, Kobieta żydowska w okupowanym Krakowie..., rozdz. IV, s. 207-210). 


\section{Rodzina Puretzów - środowisko krakowskich zasymilowanych Żydów}

We wrześniu 1939 r. Marta miała 16 lat. Była córką dr. Jakuba Puretza, zamożnego i znanego lekarza z Dębnik, jednej z dzielnic Krakowa. Marta, jej matka Rena i babka Rosa Puretz zostały natychmiast wygnane przez Niemców $\mathrm{z}$ eleganckiej kamienicy przy ul. Różanej 11 . Trafiły do getta w momencie jego utworzenia, w marcu 1941 r., podobnie jak rodziny ich krakowskich krewnych - Ignacego, dentysty z Dębnik z ul. Pułaskiego, oraz Józefa, urzędnika z ulicy Łobzowskiej. Wszyscy oni należeli do nowej warstwy spolszczonej inteligencji żydowskiej, której trzon stanowili przedstawiciele wolnych zawodów. Wykształcenie było bowiem przepustką do polskości, ponieważ integracja obywatelska dokonywała się na gruncie języka i kultury. W Krakowie dla kilkunastu procent Żydów język polski był językiem ojczystym i zasymilowani Żydzi często czuli się bliżsi polskiemu otoczeniu, w którym mieszkali, aniżeli innojęzycznym współwyznawcom. Jakub Puretz kształcił się jednak w Wiedniu, ponieważ prestiż lekarzy wiedeńskich w Krakowie był bardzo duży już od czasów autonomii galicyjskiej. Puretz miał ponadto $\mathrm{w}$ Wiedniu powiązania rodzinne. Rodziny jego matki (Propsteinów) i żony (Kornfeldów), rozgałęzione i liczne w Galicji Wschodniej, już od lat osiemdziesiątych XIX w. wyjeżdżały do Austrii na fali wielkiej żydowskiej migracji po 1880 r. Emigranci poszukiwali nie tyle chleba, ile szans na lepszą egzystencję, którą mogło zapewnić

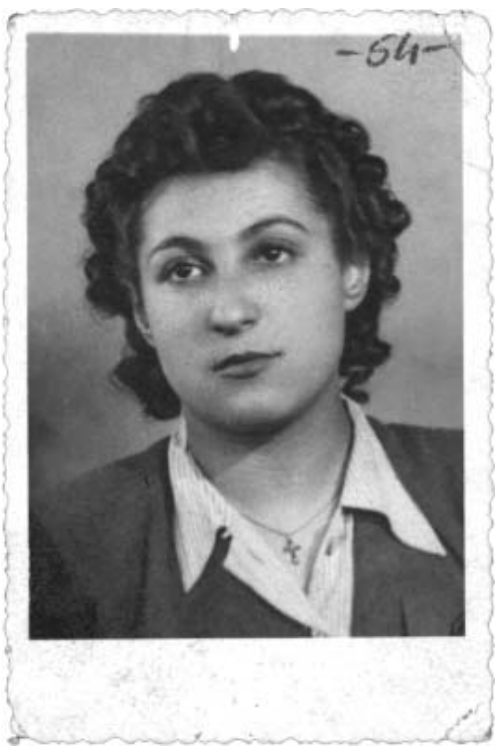
przeniesienie do odmiennej, wyższej cywilizacyjnie rzeczywistości. Owi „galitzianerzy" migrowali przede wszystkim do Wiednia i Budapesztu. W Wiedniu rodziny ulegały asymilacji i w ciągu jednego pokolenia przyjmowały język niemiecki, który był synonimem kultury wysokiej i jawił im się jako najlepsza przepustka do europejskości.

Sama Marta Puretz ${ }^{7}$ urodziła się w Wiedniu 20 czerwca 1923 r. i język niemiecki był poniekąd jej językiem ojczystym. Do Polski wraz z rodziną przyjechała w dzieciństwie. Najpierw mieszkali w Radomiu i w Trzcinicy - miejscu urodzenia jej babki - a w 1929 r. osiedli w Krakowie. Marta od 1933 do 1939 r.

${ }^{7}$ AN, 19910593/7, Martha Puretz, Akta dotyczące Marty Puretz i jej męża Charles'a Hero-

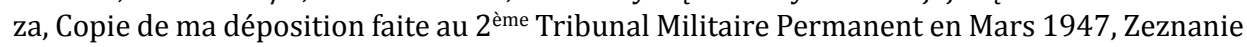
Marty Heroz, z domu Puretz, wraz z załącznikami, Saint Denis, 30 I 1947 r. 
chodziła do polskiego prestiżowego gimnazjum im. Królowej Wandy, które dobrze przygotowało ją do odbioru kultury wysokiej. Języka jidysz na pewno nie znała, języka hebrajskiego ani kultury żydowskiej także. Nie przypuszczam, aby miała wówczas wyrobione i ugruntowane poczucie tożsamości żydowskiej. Wychowywana była w środowisku polskim i co najwyżej mogła czuć się Polką wyznania mojżeszowego.

Marta wcześnie straciła ojca. Choć mieszkali w Krakowie, Jakub Puretz był związany z Ubezpieczalnią Społeczną w Chrzanowie i pracował w Trzebini. W 1935 r. zmarł w wyniku zakażenia, które wdało się w następstwie jego zranienia podczas operacji chirurgicznej.

Marta dorastała w otoczeniu kobiet niewątpliwie zaradnych. Nie były one tradycyjnymi Żydówkami. Obyte ze światem, o różnorodnych kontaktach, podejmowały samodzielne decyzje. Rena Puretz razem z dr. Adolfem Billigiem, dyrektorem Instytutu Muzycznego w Krakowie, udzieliła w 1938 r. kilkunastotysięcznej pożyczki w złocie niejakiemu Karolowi Architekowi-Redkowskiemu, obciążając hipotekę jego kamienicy w centrum Podgórza, nad brzegiem Wisły ${ }^{8}$. Trzy lata później kamienica znalazła się w getcie. Kobiety z rodziny Puretzów żyły na poziomie polskiej zamożnej inteligencji. Mała Marta miała piastunkę, w domu była służąca. Polki te, serdecznie traktowane przez rodzinę Puretzów, w czasie okupacji służyły Marcie pomocą.

Zasymilowane kobiety żydowskie miały odmienne doświadczenia od większości Żydówek z zatłoczonego Kazimierza, którego większość mieszkańców wiodła niemal orientalny styl życia ${ }^{9}$. Można domniemywać, że podobnie jak znaczna grupa zasymilowanych Żydów kobiety z rodziny Puretzów nie uczęszczały do synagogi, nie obchodziły szabatu, nie prowadziły koszernej kuchni ani nie przestrzegały innych zasad judaizmu. Im większy był stopień asymilacji, tym bardziej upodabniano styl życia do tego, jaki obowiązywał w obrębie polskiej społeczności - stroje, urządzanie mieszkań, wyjazdy na wakacje czy do kuror-

\footnotetext{
${ }^{8}$ Informację zawdzięczam uprzejmości dr. Mariana Formy, który udostępnił mi odpis księgi wieczystej nieruchomości położonej przy ul. Wita Stwosza (nazwa przedwojenna), aktualnie przy ul. Piwnej 7a.

${ }^{9}$ Profesor Karol Estreicher, historyk sztuki, tak go opisywał: „Kazimierz przypomina chwilami miasta Wschodu... Wschodni temperament mieszkańców objawia się w krzykliwie prowadzonych rozmowach, w ożywionej mimice i gestykulacji. Pod wieczór w dnie świąteczne Kazimierz cichnie i się uspokaja. Po ulicach chodzą Żydzi ubrani w długie chałaty, w czapkach obszywanych lisim futrem. Z okien domów biją światła żarzących się świec. Modlącą się ludnością zapełniają się bożnice [...] Miasto żydowskie tworzy dziwny, niepozbawiony ruchu obraz" (cyt. za: Mieczysław Czuma, Leszek Mazan, Tate, jedziemy do Krakowa!, Kraków: Anabasis, 2015, s. 227). Koloryt dzielnicy - „matki wszystkich tandet” - oddają barwne wspomnienia Rafaela Scharfa, z rodziny kazimierskich Żydów i dziennikarza Manuela Rympla (Rafael Scharf, Co mnie i Tobie Polsko... Eseje bez uprzedzeń, Kraków: Fundacja Judaica „Universitas”, 1996, s. 30; Manuel Rympel, Słowo o Żydach krakowskich w okresie międzywojennym (1918-1939) [w:] Kopiec wspomnień, Kraków: Wydawnictwo Literackie, 1964, s. 557-559).
} 
tów. Niektóre bardziej wyemancypowane Żydówki decydowały się na makijaż, obcinały krótko włosy, by uzyskać modną fryzurę chłopczycy ${ }^{10}$.

Wkroczenie Niemców do Krakowa było dla Żydów zawaleniem się ich dotychczasowego świata. Dla wszystkich Żydów - od zasymilowanych po ortodoksyjnych i syjonistów, od wykształconych i zamożnych, z lepszych dzielnic miasta, po drobnomieszczaństwo i biedotę z Kazimierza, Stradomia i części Podgórza. Od samego początku okupanci obchodzili się z nimi nieludzko, Żydzi padali ofiarą przemocy i upokorzeń. Natychmiast po wkroczeniu do Krakowa (8 września) Niemcy powołali do życia Judenrat - Radę Żydowską, której zadaniem było administrowanie społecznością i wdrażanie zarządzeń okupanta. Dotychczasowe żydowskie organizacje gospodarcze, społeczne i kulturalne przestały istnieć.

Rodzina Puretzów, wygnana z eleganckiej kamienicy, została dokwaterowana nieopodal, do domu przy ul. Polnej 1 (dzisiaj Michała Bałuckiego) ${ }^{11}$. Zimą 1939/1940 r. kobiety - jak wszyscy Żydzi od 14. roku życia - zostały objęte przymusem pracy. Za opłatą w Judenracie, który przygotowywał spisy ludności, można było znaleźć zastępcę. Rena Puretz uchroniła wtedy Martę, lecz sama wraz z teściową - Rosą - znalazły się na liście osób przewidzianych do odśnieżania miasta. Marta pracowała jako pomoc dentystyczna u dr. Aibouchetsa przy ul. Zwierzynieckiej i wzorem innych młodych ludzi uczęszczała na tajne komplety - w jej przypadku polegały one na doskonaleniu języków francuskiego i angielskiego.

Kraków, stolica Generalnego Gubernatorstwa, miał być judenrein - wolny od Żydów. W 1939 r. było ich około 60 tys. Stanowili oni ponad 25 procent ogółu mieszkańców. Napływ uchodźców wojennych zwiększył ich liczbę do prawie 70 tys. Władze niemieckie w 1940 r. zarządziły masową akcję wysiedlania Żydów na wschód, gdzie w dystrykcie lubelskim w latach 1942-1943 zginęli w obozach zagłady w Bełżcu, Sobiborze i Treblince. Zezwolenie na pobyt w Krakowie otrzymały tylko osoby niezbędne dla Niemców ze względów gospodarczych. Prawdopodobnie dzięki protekcji i korupcji w Judenracie kobiety z rodziny Puretzów załatwiły sobie zezwolenia. Najpierw, we wrześniu 1940 r., były to ausweisy. Po decyzji o przesiedleniu Żydów do getta 3 marca 1941 r. otrzymały karty rozpoznawcze - kenkarty ${ }^{12}$.

\footnotetext{
${ }^{10} \mathrm{O}$ środowiskach zasymilowanych kobiet pisze Martyna Grądzka-Rejak (eadem, Kobieta żydowska w okupowanym Krakowie..., rozdz. II, s. 106-127).

${ }^{11}$ https://www.ushmm.org/online/hsv/person_view.php?PersonId=6096356 (adres Marty Puretz); https://www.ushmm.org/online/hsv/person_view.php?PersonId=6096362 (adres Reny Puretz); https://www.ushmm.org/online/hsv/person_view.php?PersonId=6096372 (adres Rosy Puretz).

12 https://www.ushmm.org/online/hsv/person_view.php?PersonId=6096358\&ReferPersonId=6096357 (Rena Puretz); https://www.ushmm.org/online/hsv/person_view.php?PersonId=6096363\&ReferPersonId=6096364 (Rosa Puretz); https://www.ushmm.org/online/ hsv/person_view.php?PersonId=6096350 (Marta Puretz).
} 


\section{Marta w getcie i poza nim - po ucieczce z obozu płaszowskiego}

Getto krakowskie było zupełnie inne niż warszawskie czy łódzkie: średniej wielkości pod względem powierzchni i liczby ludności, specyficznie usytuowane - odcięte od miasta Wisłą i wtłoczone między prawy jej brzeg a odsłonięte, bezdrzewne wzgórza Krzemionek. Znajdowało się tam zaledwie kilkanaście ciasnych ulic wydzielonych z dzielnicy Podgórza, zatłoczonych do granic możliwości, po części opasanych murem na kształt cmentarnych żydowskich macew z czterema bramami wejściowymi. Odcięcia od zewnątrz dopełniały druty kolczaste oraz zabite bramy i okna, które wychodziły na aryjską stronę. Żydowska Dzielnica Mieszkaniowa była całkowicie bezbronna, rozciągnięta jak na dłoni dla obserwujących ją Niemców z pobliskiego wzgórza, które przechodziło nieco dalej w obóz Płaszów - najpierw pracy, potem przekształcony w koncentracyjny. Mimo przeludnienia, niedożywienia, ciężkiej pracy i strachu w pierwszych miesiącach ludzie starali się budować normalność, odtwarzając infrastrukturę gminy żydowskiej. Pieniądze, kosztowności, te przy sobie i te ukryte po aryjskiej stronie, dojścia do odemanów - żydowskich policjantów - konfidentów i poparcie niemieckich pracodawców ratowały życie, przynajmniej na jakiś czas. Kres wszelkiej nadziei położył rok 1942, który przyniósł akcje deportacyjne do obozów zagłady. Na przełomie maja i czerwca oraz w październiku tysiące ludzi przeżyły koszmar spędzania przez odemanów na pl. Zgody, skąd pod ostrzałem esesmanów Żydów gnano do wagonów, a na ulicach pozostawiano martwych.

Miejscem wytchnienia od rzeczywistości była apteka „Pod Orłem” Tadeusza Pankiewicza, jedynego tzw. Aryjczyka w getcie. Mieściła się w centralnym miejscu, w kamienicy przy ówczesnym pl. Zgody (dzisiaj Bohaterów Getta). Była czymś więcej aniżeli punktem farmaceutycznym - tu zawsze można było przyjść i porozmawiać, poczytać gazety niemieckie i prasę podziemną. Tutaj wpadało się, by zaczerpnąć ze swoistej giełdy informacji. Do apteki bowiem zachodzili także Niemcy, odemani, konfidenci i częstokroć dzielili się z właścicielem nowinami.

W getcie pojawiły się zróżnicowane postawy. Od tych prezentowanych przez działaczy Żydowskiej Samopomocy Społecznej po tych, którzy chcieli zabezpieczyć tylko siebie i własne rodziny. Pogłębiły się podziały wśród społeczności żydowskiej. Obok „starej” elity, osób zamożnych choć nielicznych, powstały „nowe” elity. Składały się nie tylko z urzędników administracji żydowskiej, ale i z szmuglerów czy złodziei, z policji żydowskiej i konfidentów Gestapo ${ }^{13}$. Idąc na współpracę, nic dotąd nieznaczący ludzie nagle zdobywali pozycję i żyli w lepszych warunkach.

Choć współpracownicy Gestapo budzili strach, to właśnie z ich pośrednictwa korzystano $\mathrm{w}$ różnych sprawach. Byli nieodzowni w kontaktach $\mathrm{z}$ aresztowanymi, przekazywaniu im wiadomości oraz ofert okupu lub łapówek urzędnikom

\footnotetext{
${ }^{13}$ Jarkowska-Natkaniec, Wymuszona współpraca..., s. 74.
} 
niemieckim. Przy pomocy współpracowników Gestapo można było załatwić legalne dokumenty - tak pożądane kenkarty. W niedużym getcie krakowskim właściwie wszyscy się znali i działalność współpracowników Gestapo była półoficjalna.

Marta Puretz znalazła się w getcie, gdy miała 18 lat. Wojna i okupacja, jak u wielu innych młodych ludzi, przyspieszyła procesy dojrzewania emocjonalnego - w sferze odpowiedzialności za rodzinę, radzenia sobie i szukania sposobów na przeżycie. Marta była młoda, świadoma własnej kobiecej atrakcyjności i ta świadomość determinowała jej zachowanie. Rodzinie udało się załatwić w Judenracie mieszkanie przy głównej arterii, ul. Tarnowskiej 1 (dzisiejszej Bolesława Limanowskiego), tuż przy bramie wejściowej do getta z Rynku Podgórskiego. Wcześniej kobiety z rodziny Puretzów zdeponowały wartościowe przedmioty u zaufanej osoby w mieście, ale zapewne część walorów zabrały ze sobą, aby pomóc sobie przetrwać ciężkie chwile. W niemieckich kartotekach formalnie głową rodziny była Rosa Puretz, tyle tylko że urodziła się ona w 1870 r., co ją w oczach Niemców z góry skazywało na śmierć. Matka Marty Puretz, Rena, urodzona w 1897 r., mieściła się w granicach obowiązku pracy, ale była wówczas dotknięta czasowym brakiem sprawności. Utrzymanie rodziny, a także walka o przeżycie jej członków spoczywały więc na Marcie. Nie udało się jej uratować babki, która została zastrzelona przez Niemców - być może podczas jednej z deportacji lub podczas likwidacji getta. Później Marcie nie udało się wyciągnąć matki z obozu płaszowskiego.

Rudawa szatynka, raczej pulchna, niewielkiego wzrostu, około $150 \mathrm{~cm}^{14}$, była atrakcyjną dziewczyną o pięknych błękitnych oczach - jak pisał Michał Weichert, przewodniczący Żydowskiej Samopomocy Społecznej ${ }^{15}$. Zwrócił na nią uwagę znany agent Gestapo Aleksander Förster, niemiecki Żyd, syn fabrykantów z Lipska, którzy przeprowadzili się do Limanowej, gdzie przyszedł na świat ${ }^{16}$. Elegancki, około czterdziestki, władał wieloma językami, aczkolwiek po polsku mówił słabo. Przed wojną podróżował po świecie jako impresario tancerek, w sierpniu 1939 r. przebywał w Krakowie z jedną z nich. Jak pisał Pankiewicz, bezpośrednio po utworzeniu getta mówiono, że Förster odegrał doniosłą rolę w szpiegostwie na rzecz Niemiec i dlatego korzystał z wielu przywilejów. Miał m.in. prawo wchodzenia i wychodzenia z getta o każdej porze dnia i nocy, bez względu na godzinę policyjną. Chodził bez białej opaski z gwiazdą Dawida, witał gestapowców podnoszeniem ręki, z wieloma z nich był na „ty”. Mówiono

${ }^{14}$ AN, 19910593/7, Zeznanie Marii Kołacz, Extraits du procès-verbal des auditions de témoins dans l'affaire Matta Puretz au Cabinet du Procureur près la Cour de Justice de Cracovie, dans les journées du 6 et du 7 Août 1946 ( $N^{\circ}$ du dossier: I Dsspec 151/46), Déposition du témoin Elzbieta Jasinska, Déposition du témoin Maria Kolacz.

${ }^{15}$ Grądzka-Rejak, Kobieta żydowska..., s. 202.

${ }^{16}$ Jarkowska- Natkaniec, Wymuszona współpraca..., s. 318. 
nawet, że miał osobny pokój w głównym gmachu Gestapo przy ul. Pomorskiej ${ }^{17}$. Co było ewenementem w getcie, sam jeden zajmował trzypokojowe mieszkanie przy głównej arterii getta, ul. Tarnowskiej 1, a w sąsiedniej kamienicy, przy Rynku Podgórskim 15, tuż przy wejściu do getta, miał restaurację z dancingiem - Café Restaurant Varieté „Polonia” - w której przygrywał do tańca znany przedwojenny zespół jazzowy Rosner's Players ${ }^{18}$. W restauracji bywali Niemcy, bywał komendant odemanów i konfidenci. Tutaj wymieniano informacje i przeprowadzano transakcje. Förster często wynajmował lokal na przyjęcia w zamkniętym gronie. Urządzał huczne zabawy dla większych i mniejszych dygnitarzy, które przeciągały się do późnych godzin nocnych. Był doskonale poinformowany o tym, co dzieje się w getcie i na mieście.

W krakowskim getcie Martę Puretz zaczęto kojarzyć z działalnością Förstera, Marta bowiem prowadziła mu dom. Można przypuszczać, że widywano ją nie tylko z nim, ale i w towarzystwie jego gości. Pierwotnie - znalazłszy się w getcie - jęła się pierwszej lepszej pracy, czyli przy wyrobie szczotek. Ponieważ w kartotekach niemieckich pod rubryką zawód podała „pomoc dentystyczna”, udało się jej później dostać do gabinetu niejakiego Steckiego, dentysty z Bronowic. Jego zaświadczenia, opatrzone pieczątką, umożliwiały opuszczanie getta, dzięki czemu Marta zdobywała żywność. Dentysta jednak wyjechał w 1942 r. i wtedy wkroczył na scenę Förster, który już wcześniej zwrócił uwagę na Martę. Odkrył, że dentysty nie ma w Krakowie i w wyniku jego doniesienia Marcie zabroniono wychodzić z getta. Wtedy sam ją zatrudnił jako służącą. Od tego momentu Marta rzadko pojawiała się w getcie sama, niekiedy widywano ich razem także w Krakowie. Förster był bardzo o nią zazdrosny ${ }^{19}$. Można zatem domniemywać, iż łączyły ich intymne relacje - dawał zresztą dowody tej szczególnej więzi, niejeden raz ratując Martę z opresji.

${ }^{17}$ Tadeusz Pankiewicz, Apteka w getcie krakowskim, Kraków: Wydawnictwo Literackie, 2015, s. 51-52.

${ }^{18}$ Pierwotnie adres Förstera - ul. Tarnowska 1 - ustaliłam pośrednio na podstawie: AN, 19910593/7, Deklaracja Blumy Preiss, Planegg (Bawaria), 28 V 1948 r. (kopia tłumaczenia na język francuski [HV19313]). Natomiast dowodu bezpośredniego bezdyskusyjnie dostarczyło mi zeznanie Stanisławy Skiminy, Żydówki ukrywającej się po aryjskiej stronie, która udała się do Förstera, aby załatwić wypuszczenie jej męża z więzienia: „Początkowo rozmawialiśmy w ogródku na ławce przed domem Förstera, a następnie Krzyżańska [jego przyjaciółka - A.K.Ch.] zaprowadziła nas do mieszkania Förstera znajdującego się na drugim piętrze. Weszliśmy do dużego pokoju [...]. Okna pokoju wychodziły na ulicę Limanowskiego" (cyt. za: Jarkowska-Natkaniec, Wymuszona współpraca..., s. 321). Ponieważ mieszkam przy Rynku Podgórskim 15 i znam dobrze topografię obu kamienic, mogę potwierdzić z autopsji, iż adresem Förstera była ówczesna Tarnowska 1. Adres restauracji - Rynek Podgórski 15 podaję na podstawie: Pankiewicz, Apteka w getcie krakowskim..., s. 52; Jarkowska-Natkaniec, Wymuszona współpraca..., s. 318, przypis 296.

${ }^{19}$ AN, 19910593/7, Déclation de Mlle Feliksiak Maria au sujet de Mme Heroz, née Puretz, 1948 r. (kopia tłumaczenia na język francuski oświadczenia złożonego w konsulacie francuskim w Krakowie, 19 IV 1948 r.). 
Tajemniczy agent, pozostający w dobrych stosunkach z Niemcami, miał możliwość skutecznej interwencji w Gestapo. Wielu Żydów z getta wierzyło w to, starając się do niego zbliżyć. Marta Puretz była cichą pośredniczką tych akcji. Dowodzą tego późniejsze, powojenne zeznania kobiet, które ją wtedy dobrze znały z getta. Pisały, że jej postawa była bez zarzutu. Pomagała każdemu i w każdym wypadku - jak ujęła to Gisèle Fendler: „Pomagała swojemu, na ile tylko mogła"20. Bluma Preiss, która mieszkała z Martą od połowy 1941 do marca 1943 r., zaświadczyła: „Wiem, że pani Puretz w tym czasie, z pomocą pewnego Żyda, który mieszkał w tym samym domu, uratowała życie i wolność wielu Żydom". Preis była przekonana, że Marta nie mogła posunąć się do denuncjacji, ponieważ było to sprzeczne z jej mentalnością i postawą ${ }^{21}$.

W czasie wydawania pieczątek na pobyt w getcie i w czasie wysiedleń Förster dał się bliżej poznać - i to od ludzkiej strony. Uzyskiwał pieczątki dla ludzi, którzy w inny sposób nie mogli pozostać w getcie. Podczas deportacji interweniował na rzecz niektórych Żydów, już wyselekcjonowanych do wysiedlenia, i wyciągał ich z transportu. Pankiewicz uważał - i potwierdzali to inni - że jeśli chodzi o zachowanie w getcie, to Försterowi nie można było nic zarzucić. Wprawdzie pośredniczył za pieniądze i prezenty, ale zdarzało się, że i bezinteresownie. Dzięki temu ratował niektórych ludzi, a nieraz nawet ułatwiał im ucieczkę $e^{22}$.

Jesienią 1942 r. - po tragicznych akcjach deportacyjnych do obozu zagłady coraz więcej Żydów decydowało się na ucieczkę z getta. Zapewne Rena Puretz z córką podjęły dramatyczną decyzję ratowania Marty w taki właśnie sposób. We wrześniu Marta udała się do Elżbiety Jasińskiej ${ }^{23}$, znanej jej sprzed wojny fryzjerki z Dębnik, która mieszkała przy tej samej ul. Pułaskiego, gdzie przed 1939 r. żył wujek Marty - Józef Puretz. Wieś Dębniki dopiero w początkach XX w. została przyłączona do Krakowa i stała się jedną z podmiejskich dzielnic, z rynkiem i kilkoma ulicami, które przechodziły w pola z wiejską zabudową. W takim miejscu ludzie znali się dobrze, a wiadomości rozchodziły się bardzo szybko.

${ }^{20}$ Ibidem, Deklaracja Gisèle Fendler, więźniarki obozu koncentracyjnego Auschwitz, Londyn, 21 IV 1948 r. (kopia tłumaczenia na język francuski [ZS31099]).

${ }^{21}$ Ibidem, Deklaracja Blumy Preiss, Planegg (Bawaria), 28 V 1948 r. (kopia tłumaczenia na język francuski [HV19313]). Preiss napisała: „Je considère comme absolument impossible, que Madame PURETZ, contrairement à toute son attitude et mentalité, ait pu jamais aller jusqu'à dénoncer quelqu'un ou à l'entraîner dans le malheur, je sais au contraire que tant que j'ai été avec elle, elle a toujours aidé son prochain, partout et de toutes les manière où cela lui a été possible".

${ }^{22}$ Pankiewicz, Apteka w getcie krakowskim..., s. 54.

${ }^{23}$ AIPN Kr, 010/6637, Protokół przesłuchania Elżbiety Jasińskiej, WUBP, Kraków, 16 V 1946 r.; AN, 19910593/7, Déposition du témoin Maria Kolacz, Extraits du procès-verbal des auditions de témoins dans l'affaire Matta Puretz au Cabinet du Procureur près la Cour de Justice de Cracovie, dans les journées du 6 et du 7 Août 1946 ( $N^{\circ}$ du dossier: I Dsspec 151/46), Déposition du témoin Elzbieta Jasinska, Déposition du témoin Maria Kolacz. Zeznania Elżbiety Jasińskiej w prokuraturze są bogatsze w szczegóły. 
Elżbieta Jasińska miała kontakty z podziemiem i Marta o tym wiedziała, więc poprosiła ją o wyrobienie fałszywej kenkarty, aby przedostać się za granicę. Marta przychodziła kilkakrotnie, lecz nie miała jeszcze zgromadzonej znacznej sumy 2 tys. zł. Kiedy 20 października zgłosiła się po dokumenty z pieniędzmi, podjechało Gestapo i zgarnęło wszystkich obecnych w lokalu. Tylko Jasińska jednak i człowiek z podziemia zostali skazani za próbę sporządzenia fałszywych dokumentów i wysłani do Auschwitz. Tak naprawdę nie sposób dowieść, czy była to prowokacja, w której użyto Marty, czy być może ona sama, na własną rękę, chciała sobie załatwić kenkartę, a ktoś trzeci poinformował o tym Gestapo. Niemcy zresztą od dawna obserwowali rodzinę, która współpracowała z podziemiem od 1940 r. Aresztowali za to ojca Jasińskiej, który zginał później w Auschwitz, a także siostrę, Marię Kołacz, którą zesłali do Ravensbrück na dwa lata za kolportaż prasy podziemnej ${ }^{24}$. Po aresztowaniu Elżbiety Jasińskiej w prasie AK pojawiło się ostrzeżenie przed Martą Puretz. Nie było jej jednak wśród konfidentów spisywanych przez Pankiewicza na receptach, a właściciel apteki „Pod Orłem” był doskonale poinformowany. Faktem jest, że Marta, dzięki temu, iż prowadziła dom Försterowi, poznała niektórych gestapowców i co znaczniejszych konfidentów, którzy się tam przewijali, i nietrudno ją było z nimi kojarzyćc ${ }^{25}$.

Sama Marta po dwóch dniach została zwolniona z aresztu przy ul. Pomorskiej i - jak zeznała po wojnie jej niania Maria Feliksiak - zawdzięczała to interwencji Förstera na Gestapo ${ }^{26}$. Później - w lutym 1943 r. - Marta przekonywała

${ }^{24}$ Po wojnie, na pytanie oficera śledczego WUBP przesłuchującego Elżbietę Jasińską, jakie okoliczności w jej sprawie mogą zaświadczyć, że aresztowanie nastąpiło wskutek donosu Puretz, odpowiedziała: „Przed wojną pracowałam w Turze, prowadziłam obóz czerwonych harcerzy, o tym wiedziała Puretz i o tym wiedziało Gestapo". Skoro rodzina Jasińskiej była pod obserwacją, Niemcy mogli już wcześniej posiadać takie informacje.

${ }^{25}$ Rozpracowywaniem i zwalczaniem współpracowników Gestapo, w tym żydowskich konfidentów, zajmowały się organizacje podziemne. Pierwsze informacje o nich - m.in. o Försterze - pojawiły się już jesienią 1940 r. Autorami raportów o żydowskich kolaborantach byli członkowie krakowskiego Kedywu lub Zgrupowania „Żelbet”, działającego w ramach AK. Raporty podawały miejsca spotkań podejrzanych o współpracę, ich nazwiska i adresy zamieszkania. Małopolska Agencja Prasowa donosiła, że w Krakowie działały dwa zespoły agentów, skupione wokół Maurycego Diamanta i Aleksandra Förstera. Martę Puretz wiązano z Försterem. Nie wiadomo, czy działały one odrębnie, czy w ramach zorganizowanej siatki agenturalnej. Źródła, a za nimi literatura, łączyły dwie grupy w siatkę agenturalną - tzw. siatkę Diamanta (12 osób). Jej członkom przypisywano przede wszystkim działalność wymierzoną w polskie podziemie. Natomiast w dokumentach żydowskich osób zaliczonych przez podziemie do siatki Diamanta nie łączono z taką działalnością. Zarzucano im działania stricte antyżydowskie - wydawanie ukrywających się Żydów czy przejmowanie ich majątków (Jarkowska-Natkaniec, Wymuszona współpraca..., s. 270, 272, 280-283).

${ }^{26}$ AN, 19910593/7, Déclation de Mlle Feliksiak Maria au sujet de Mme Heroz, née Puretz, 1948 r. (kopia tłumaczenia na język francuski oświadczenia złożonego w konsulacie francuskim w Krakowie, 19 IV 1948 r.). 
spotkaną na ulicy Marię Kołacz, że nie była winna temu, iż jej siostra została aresztowana. Nie uwierzono jej. Podziemie próbowało zgładzić Martę Puretz, wykorzystując siostrę Jasińskiej do jej rozpoznania, ale akcja się nie udała ${ }^{27}$. Marta była już przygotowana do ucieczki z getta. Miała fałszywe dokumenty na nazwisko Maria Panecka. Zapewne uzyskała je dzięki Försterowi. Człowiek z podziemia nie zdążył ich wykonać przed aresztowaniem na jednym z pustych blankietów, które przechowywała u siebie Elżbieta Jasińska. Poza zameldowaniem, zaświadczeniem o pracy i kenkartą Marta musiała mieć metrykę chrztu - zapewne dlatego na zdjęciu ma krzyżyk, który ją uwiarygodniał. Chciała uciec przez Węgry do Rumunii. Nie zdążyła. 13 marca 1943 r., o piątej rano, Niemcy obstawili getto i wszystkich dorosłych zdolnych do pracy zagnali do obozu płaszowskiego.

Marcie udało się przekupić stosownych ludzi i opuściła obóz ${ }^{28}$. Prawdopodobnie oficjalnie dołączyła do tzw. Säuberungskolonne - ludzi z baraków płaszowskich, którzy uprzątali getto. Zbiegła z Płaszowa i dotarła na Dębniki, na ul. Różaną 15. Tutaj mieszkały dwie zaufane osoby, zżyte z rodziną Puretzów i jej oddane - Maria Feliksiak, niania Marty od 1926 r., i Salomea Feliksik, służąca od 1934 r. Marta ukrywała się u nich dwa tygodnie. Wówczas została rozpoznana na ulicy przez męża Elżbiety Jasińskiej - Bolesława. Z zemsty zadenuncjował ją polskiemu policjantowi granatowemu jako Żydówkę, która nie nosząc opaski z gwiazdą Dawida, podszywa się pod „Aryjkę”. Ten z kolei oddał ją w ręce policji niemieckiej ${ }^{29}$. I tym razem Marta została zwolniona, ponieważ Aleksander

${ }^{27}$ AIPN Kr, 010/6637, Protokół przesłuchania Marii Kołacz, WUBP, Kraków, 16 V 1946 r.; AN, 19910593/7, Déposition du témoin Maria Kolacz, Extraits du procès-verbal des auditions de témoins dans l'affaire Matta Puretz au Cabinet du Procureur près la Cour de Justice de Cracovie, dans les journées du 6 et du 7 Août 1946 ( $N^{\circ}$ du dossier: I Dsspec 151/46), Déposition du témoin Elzbieta Jasinska, Déposition du témoin Maria Kolacz.

Marta Puretz pracowała wówczas w niemieckiej mleczarni przy ul. Smoleńsk, lecz na pół godziny przed nadejściem Marii Kołacz wraz z człowiekiem z konspiracji opuściła mleczarnię i więcej się tam nie pojawiła. Dlaczego była tam zatrudniona, skoro prowadziła dom Försterowi? Nie zapominajmy, że wówczas tylko praca w niemieckim zakładzie dawała jej możliwość poruszania się poza gettem - oprócz wychodzenia na miasto z Försterem. Od grudnia 1942 r. pracujący mieszkańcy getta musieli mieć przy sobie niebieskie karty tożsamości z literą informujacą, przy jakiego typu zajęciach są zatrudnieni.

${ }^{28}$ AN, 19910593/7, Copie de ma déposition faite au $2{ }^{\text {ème }}$ Tribunal Militaire Permanent en Mars 1947, Zeznanie Marty Heroz, z domu Puretz, wraz załącznikami, sporządzone w Saint Denis, 30 I $1947 \mathrm{r}$.

Dalszy bieg wydarzeń w Polsce relacjonuję na podstawie oświadzeń złożonych przez Marię Feliksiak w konsulacie francuskim w Krakowie 19 IV 1948 r. (AN, 19910593/7, Déclation de Mlle Feliksiak Maria au sujet de Mme Heroz, née Puretz; Déclation de Mlle Salomea Feliksik au sujet de Mme Heroz, née Puretz).

${ }^{29}$ AIPN Kr, 010/6637, Protokół przesłuchania Marii Kołacz, WUBP, Kraków, 16 V 1946 r;; AN, 19910593/7, Dépositon du témoin Maria Kolacz, Extraits du procès-verbal des auditions de témoins dans l'affaire Matta Puretz au Cabinet du Procureur près la Cour de Justice de Cra- 
Förster - powiadomiony o tym fakcie przez Marię Feliksiak - zdążył interweniować $^{30}$.

Marta przeniosła się na ul. Sereno Fenna, do zaprzyjaźnionej rodziny Groty-Prokopowicz, gdzie znajdowały się meble Puretzów i biżuteria. Z Marią Feliksiak, wręcz jej powiernicą, spotykała się regularnie, raz do dwóch razy w tygodniu. Zwierzała się, że ma znajomych i gdyby miała 35 tys. zł, to dzięki ich pośrednictwu mogłaby się przedostać na Węgry. Spieniężyła meble i biżuterię i przez kilka miesięcy nadal się ukrywała, przemieszczając pomiędzy mieszkaniami dziewięciu znajomych osób i ich rodzin. Oprócz państwa Groty-Prokopowicz - o niemieckich korzeniach, wpisanych na volkslistę - byli to polscy dentyści, lekarz oraz kilka innych osób o żydowsko brzmiących nazwiskach ${ }^{31}$. Tuż przed ucieczką za granicę Marta przebywała u Förstera ${ }^{32}$. Przez cały czas usiłowała za wszelką cenę doprowadzić do wydostania matki z obozu płaszowskiego, na co wydała prawie cały spieniężony rodzinny majątek. Nie udało się jej tego osiągnąć i w listopadzie 1943 r. potajemnie, wraz z osiemnastoma innymi osobami, przez Słowację przedostała się na Węgry ${ }^{33}$. Stamtąd nadal utrzymywała listowny kontakt z Marią Feliksiak.

\section{W węgierskim potrzasku}

W Budapeszcie w czasie wojny pieczę nad uciekinierami sprawował Komitet Obywatelski do spraw Opieki na Polskimi Uchodźcami, który stanowił inną formę Delegatury Polskiej, zamkniętej w 1940 r. przez Węgry, państwo sprzymierzone z hitlerowską Rzeszą. Uciekinierzy z Polski legalizowali dokumenty w Komitecie, gdzie uzyskiwali potwierdzenie, że są obywatelami polskimi wyznania katolickiego. Komitet Obywatelski wypłacał każdemu zalegalizowanemu comiesięczną zapomogę z funduszy państwowych i charytatywnych. Z Polskiego Komitetu dokumenty trafiały do ponownej legalizacji na węgierską policję do

covie, dans les journées du 6 et du 7 Août 1946 ( $N^{0}$ du dossier: I Dsspec 151/46), Déposition du témoin Elzbieta Jasinska, Déposition du témoin Maria Kolacz.

${ }^{30}$ AN, 19910593/7, Déclation de Mlle Feliksiak Maria au sujet de Mme Heroz, née Puretz, Kraków, 19 IV $1948 \mathrm{r}$.

${ }^{31}$ Ibidem, Copie de ma déposition faite au $2^{\text {ème }}$ Tribunal Militaire Permanent en Mars 1947, Zeznanie Marty Heroz, Saint Denis, 30 I 1947 r. wraz z załącznikami: Liste de témoins № 1 Personnes qui m’ont hébergé et caché en Pologne. Zob. Aneks, Lista świadków nr 1.

${ }^{32}$ AN, 19910593/7, Déclaration de Mlle Feliksiak Maria au sujet de Mme Heroz, née Puretz, Kraków, 19 IV 1948 r. Co ciekawe, Marta Puretz nie wymieniła Förstera wśród osób, które ukrywały ją w Polsce. Dlaczego? Tu można tylko snuć przypuszczenia. Być może, wiedząc jaką rolę odgrywał jako agent Gestapo i obawiając się o swoją wiarygodność, nie chciała, by ją z nim kojarzono.

${ }^{33}$ AN, 19910593/7, Copie de ma déposition faite au $2^{\text {ème }}$ Tribunal Militaire Permanent en Mars 1947, Zeznanie Marty Heroz, z domu Puretz, wraz załącznikami, sporządzone w Saint Denis, 30 I 1947 r. 
spraw cudzoziemców. W ten sposób policja miała sposobność do ich ciągłego kontrolowania, ponieważ musieli stawiać się co pewien czas po prolongatę legalizacji. Bez prolongaty nie mogli wynająć mieszkania, bezpiecznie poruszać się po ulicach ani otrzymać kartek żywnościowych na chleb, cukier itp. Marta zadeklarowała, że jest chrześcijanką o nazwisku Maria Panecka, i zamieszkała w Budapeszcie, pierwotnie w pensjonacie Salay, a później w prywatnym mieszkaniu przy ul. Vörörosmarty $59^{34}$.

W styczniu 1944 r. Marta nieopodal przedstawicielstwa francuskiego w Budapeszcie poznała Bernarda Ginsbourga, francuskiego uciekiniera, byłego jeńca wojennego. Uroda Marty, jej sposób bycia, dobra francuszczyzna i wspólny los uchodźców sprawiły, że się polubili. Rychło Ginsbourg przedstawił Marcie swojego kolegę Charles'a Heroza, również uciekiniera z obozów jenieckich, zatrudnionego w Legacji francuskiej. To właśnie on, początkowo tylko kolega, stał się dla Puretz najbliższą osobą.

10 marca 1944 r. węgierska policja aresztowała Martę, podejrzewając, że jest Żydówką. Została internowana w obozach w Budapeszcie - najpierw przy ul. Rombach, a później Magdolna. Wkrótce w obozie Magdolna pojawili się francuscy przyjaciele z wiadomością, że 19 marca Niemcy zajęli Węgry i gorąco namawiali ją, aby jak najszybciej zbiegła. Udało się jej wydostać z obozu pod koniec marca. Przez 3 dni przechował ją Charles Heroz. Lecz ani on, ani jego przyjaciel nie mogli przyjść jej z pomocą, ponieważ im samym jako uciekinierom z niemieckich obozów groziło aresztowanie.

Marta znalazła się w tragicznej sytuacji - bez legalnych dokumentów, zapomogi z Polskiego Komitetu Obywatelskiego, mieszkania, ścigana przez policję. Zdana na przypadkową życzliwość i przelotne kryjówki, trafiła na niejakiego Stanisława Fabera ${ }^{35}$, Żyda z Krakowa ${ }^{36}$, któremu bezpieczeństwo zapewniały

${ }^{34}$ Jej koleje losu na Węgrzech są szczegółowo referowane na podstawie: AN, 19910593/7, Copie de ma déposition faite au $2^{\text {ème }}$ Tribunal Militaire Permanent en Mars 1947, zeznanie Marthe Heroz, z domu Puretz, wraz załącznikami, sporządzone w Saint Denis, 30 I 1947 r. ibidem, Copie de ma déposition faite au $2^{\text {ème }}$ Tribunal Militaire Permanent à Paris en Mars 1947, zeznanie Charles'a Heroza, Saint Denis, 30 I 1947 r. wraz z listą świadków jego aktywności na Węgrzech; ibidem, Memoire à l'attention de Monsieur le Ministre de la Justice, faisant suite à mes lettres du: 27 janvier, 18 février et 2 mars 1948, relatives à la procédure d'extradution de mon épouse Marthe Heroz, née Puretz, Charles Heroz, Saint Denis, 20 mars 1948, 13 pièces jointes, numérotées de 1 à 13.

${ }^{35}$ Wymieniony jest $\mathrm{z}$ imienia w trzech załącznikach do pisma Charles'a Heroza z 20 III 1948 r. (AN, 19910593/7, Memoire à l'attention de Monsieur le Ministre de la Justice, faisant suite à mes lettres du: 27 janvier, 18 février et 2 mars 1948, relatives à la procédure d'extradution de mon épouse Marthe Heroz, née Puretz, Charles Heroz, Saint Denis, 20 III 1948 r., 13 pièces jointes, numérotées de 1 à 13. Są to oświadczenia: Ginsburg Bernard, Paris, 1 III 1948 r., załącznik nr 2; Bordatto Jean, Paris, 3 mars 1948, załącznik nr 9; Vigier André, Drancy, 27 II 1948 r.).

${ }^{36}$ Miał fałszywe dokumenty wystawione dla obywatela Argentyny, które zwalniały go $\mathrm{z}$ obowiązku zamieszkiwania na terenie getta krakowskiego. Aresztowany z początkiem 
fałszywe dokumenty argentyńskie. Znany był w środowisku polskim i francuskim jako podejrzany typ prowadzący niejasne interesy. Mimo wszystko w danym momencie był dla Marty wybawieniem. Ona sama - podobnie jak niegdyś na Försterze - zrobiła na Faberze piorunujące wrażenie. Ważnym atutem była jej atrakcyjność. Nie zawahała się, aby wykorzystać ją do uzyskania ochrony. Faber zaproponował jej schronienie, załatwił dokumenty z Legacji szwedzkiej na nazwisko Maria Wolanecka, a nawet ofiarował się z dostarczeniem takich samych dla matki w Polsce, przez co Rena Puretz - już pod opieką władz szwedzkich - mogłaby uratować się przed obozem koncentracyjnym. Marta zamieszkała z Faberem u rodziny Schuchnerów w Budapeszcie przy ul. Khun 12. Od tego momentu było coraz gorzej i coraz bardziej dwuznacznie. Faber zażądał od niej 2 tys. zł na uwolnienie matki, które miały być przekazane do Krakowa za pośrednictwem pracownicy w jego zakładzie, ponieważ wówczas już cała rodzina Fabera była na Węgrzech. Pieniądze otrzymał - być może były to resztki, jakie Marcie zostały ze spieniężonego w Polsce majątku, a być może otrzymała je od francuskich przyjaciół. Rena Puretz nigdy jednak nie wyszła na wolność. Faber musiał opuścić dom Schuchnerów, ponieważ dopuścił się oszustw wobec tej rodziny. Marta, formalnie jego narzeczona, przeniosła się z nim do innego lokum, przy ul. Bertalan Lajos, gdzie zamieszkali z rodziną Evy Stapp z Krakowa. Stopniowo wychodziły na jaw ciemne sprawy Fabera, który handlował dewizami i fałszywymi dokumentami. Prostacki, bez wykształcenia (Marta z Evą nazywały go „tuman”), urządzał awantury i groził im, że zatelefonuje na znany mu numer i odda je w ręce Gestapo ${ }^{37}$. Marta, mimo odrazy, żyła z nim pod jednym dachem. Dlaczego? Odpowiedź pozostaje tylko w sferze przypuszczeń. Dlaczego Marta, zdolna do niejednego ryzyka, $\mathrm{w}$ istocie zakochana w Charlesie Herozie, tkwiła w związku, który wiązał jej ręce i upokarzał? Może krył się za tym szantaż ze strony Fabera? Groźba, że ją skompromituje na Węgrzech przez ujawnienie jej związków ze znanym agentem Försterem? Faber był z Krakowa i doskonale orientował się w tym, co działo się w krakowskim getcie.

W czerwcu 1944 r. Stanisław Faber i jego rodzina zostali zatrzymani w obławie policyjnej. Marta musiała uciekać. Było to wybawieniem od Fabera, ale jednocześnie wiązało się z dramatem ponownej ucieczki i koniecznością szukania nowego schronienia. W pierwszym momencie ukrył ją Bernard Ginsbourg. W tym czasie Charles Heroz znalazł usłużną właścicielkę hotelu w Budapeszcie, która zechciała im dać potajemne schronienie. Zgodziła się pod warunkiem, że

1943 r., zbiegł po miesiącu, ukrywał się do czerwca, po czym przedostał na Węgry (Jarkowska-Natkaniec, Wymuszona współpraca..., s. 337, przypis 363).

${ }^{37}$ AN, 19910593/7, List Ewy Stapp do Marty, Warszawa, 1 III 1948 r., załącznik nr 1 do pisma Charles'a Heroza z 20 III 1948 r., Memoire à l'attention de Monsieur le Ministre de la Justice, faisant suite à mes lettres du: 27 janvier, 18 février et 2 mars 1948, relatives à la procédure d'extradution de mon épouse Marthe Heroz, née Puretz, Charles Heroz, Saint Denis, 20 mars 1948, 13 pièces jointes, numérotées de 1 à 13. 
Marta nie będzie opuszczać pokoju. Puretz i Heroz zamieszkali w Budapeszcie przy ul. Nogybanya 61/a, w domu Karoly Beck. Od czerwca do października 1944 r. Marta pozostawała w ukryciu.

Tymczasem Faber ponownie pojawił się Budapeszcie. Zazdrosny i wściekły, zaczął nękać Charles'a, wydzwaniając do Legacji francuskiej z groźbami zemsty. Jako eksnarzeczony posunął się nawet do anonimów, które wysyłał do kpt. Roosa, przełożonego Biura Internowanych Francuzów, w którym pracował Charles.

Prawnik z wykształcenia, starszy sierżant z I Regimentu Piechoty Kolonialnej, Charles Heroz do niewoli niemieckiej dostał się podczas kampanii francuskiej w czerwcu 1940 r. Był internowany w Austrii, trzy razy podejmował próby ucieczki. Dwie nieudane kosztowały go pobyty w obozach karnych na ziemiach polskich, w Rawie Ruskiej i Kobierzynie. Za trzecim razem, w grudniu 1943 r., zbiegł ze Stalagu XVII B w Austrii i dotarł na Węgry. Oddał się do dyspozycji attaché wojskowego w Poselstwie francuskim w Budapeszcie, który powierzył mu sprawy uciekinierów francuskich. Formalnie był urzędnikiem ataszatu od grudnia 1943 do lipca 1945 r. Podjął działalność na rzecz Wolnej Francji w budapeszteńskiej podziemnej komórce ruchu oporu, utworzonej przez oficerów $\mathrm{z}$ ataszatu. Jako sekretarz biura miał swój udział w wielu działaniach, takich jak pomaganie zbiegłym jeńcom, dostarczanie fałszywych dokumentów, wspieranie dezercji Francuzów z Alzacji i Lotaryngii wcielonych do Wermachtu, przerzuty uciekinierów w miejsca operacji wojskowych na Słowacji, zbieranie informacji na temat państw $0 \mathrm{si}^{38}$. Marta wspomagała Charles'a w jego pracy, a pozostając zawsze $\mathrm{w}$ domu, pełniła niejako funkcję dyżurnej. Jako jego narzeczona była znana wśród internowanych i zżyła się z nimi. W pewnym momencie, z racji jego obowiązków, w lecie 1944 r. oboje udali się na Słowację, gdzie gościł ich i ukrywał w swojej posiadłości Imre Kovacs, lecz w pośpiechu musieli ją opuścić, ponieważ nieopodal zakwaterowano niemiecki batalion piechoty ${ }^{39}$.

Na Węgrzech było coraz bardziej niebezpiecznie. Od października 1944 r., za zezwoleniem Niemiec, władzę objęła faszystowska formacja strzałokrzy-

${ }^{38}$ AN, 19910593/7, Oświadczenie płk. André Halliera, byłego attaché wojskowego Węgier, Paryż, 7 IX 1945 r., załącznik nr 7 do Memoriału Charles'a Heroza z 20 III 1948 r., tekst potwierdzenia z ministerstwa wojny nadania Charles'owi Herozowi „Médaille des Evadés”, Paryż, 27 VI 1946 r., załącznik nr 6 do Memoriału Charles'a Heroza z 20 III 1948 r., Memoire à l'attention de Monsieur le Ministre de la Justice, faisant suite à mes lettres du: 27 janvier, 18 février et 2 mars 1948, relatives à la procédure d'extradution de mon épouse Marthe Heroz, née Puretz, Charles Heroz, Saint Denis, 20 mars 1948, 13 pièces jointes, numérotées de 1 à 13; Copie de ma déposition faite au $2^{\text {ème }}$ Tribunal Militaire Permanent à Paris en Mars 1947, zeznanie Charles'a Heroza, Saint Denis, 30 I 1947 r. wraz z listą świadków jego aktywności na Węgrzech.

${ }^{39}$ Ibidem, Oświadczenie Imré Kovacsa, Nogent s/Marne, 25 II 1948 r., załącznik nr 3 do Memoriału Charles'a Heroza z 20 III 1948 r., Memoire à l'attention de Monsieur le Ministre de la Justice, faisant suite à mes lettres du: 27 janvier, 18 février et 2 mars 1948, relatives à la procédure d'extradution de mon épouse Marthe Heroz, née Puretz, Charles Heroz, Saint Denis, 20 mars 1948, 13 pièces jointes, numérotées de 1 à 13. 
żowców. Gdy pod koniec miesiąca rozpoczęło się przeczesywanie Budapesztu, w obawie przed zarządzonym spisem ludności w ich dotychczasowej dzielnicy Charles i Marta opuścili dom Karoly Beck. Na jakiś czas schronili się u rodziny syna Kovacsa, Paula, w domu przy ul. Viola 18. Na początku grudnia Charles znalazł nowy azyl u Beli Hoffmanna. Przenieśli się z Martą do domu przy ul. Plozs Lajos 12 /b, gdzie spotkały ich dramatyczne wydarzenia.

20 grudnia Gestapo aresztowało Charles'a Heroza ${ }^{40}$, podobnie jak konsula francuskiego i trzydziestkę innych Francuzów. Na wieść o tym Marta, nie tracąc przytomności umysłu, podjęła inicjatywę i zniszczyła archiwum kompromitujące Charles'a (dokumenty, pieczątki, fałszywe dowody tożsamości) ${ }^{41}$. Kilka dni później, 25 grudnia 1944 r., rozpoczęły się zmasowane ataki Armii Czerwonej na Budapeszt. Marta przetrwała je w piwnicy sąsiedniej kamienicy, kryjąc się tam z jednym z internowanych Francuzów. 13 lutego 1945 r. skończyło się oblężenie miasta. Marta wyszła z kryjówki, a Charles'a uwolniły oddziały radzieckie. Oboje przeżyli i chcieli jak najszybciej wrócić do normalności. Podjęli natychmiastową decyzję o małżeństwie - zawarli je 19 lutego 1945 r. przed urzędnikiem II dzielnicy Budapesztu ${ }^{42}$. Marta miała 22 lata, a Charles siedem lat więcej. Jak sam wyznał później, ze zwierzeń Marty znał tylko jej tragiczny los sprzed poznania się, a dopiero potem miał możność docenić jej przymioty. Chciał jej wynagrodzić wszystkie krzywdy i stworzyć rodzinę, dom, godne i należne jej życie ${ }^{43}$. Ich ślub był uroczyście świętowany w obecności konsula francuskiego w Budapeszcie.

Po wejściu Rosjan w lutym i marcu oficerowie francuscy tworzyli oddziały $\mathrm{z}$ uciekinierów i gromadzili ich wraz rodzinami w obozie w Tura, blisko Budapesztu. Małżeństwo Herozów znalazło się tam również. Komendę w Tura sprawował kpt. Roos, najstarszy rangą oficer, lecz naczelne dowództwo i ścisła kontrola obozu były w rękach rosyjskich.

${ }^{40}$ Ibidem, Oświadczenie kpt. Augusta Lavergne i por. Rogera Kleina, którzy razem z Charles'em Herozem byli więzieni przez Gestapo od 20 XII 1944 do 12 II 1945 r., załącznik nr 4 do Memoriału Charles'a Heroza z 20 III 1948 r., Memoire à l'attention de Monsieur le Ministre de la Justice, faisant suite à mes lettres du: 27 janvier, 18 février et 2 mars 1948, relatives à la procédure d'extradution de mon épouse Marthe Heroz, née Puretz, Charles Heroz, Saint Denis, 20 mars 1948, 13 pièces jointes, numérotées de 1 à 13.

${ }^{41}$ Ibidem, Poświadczenie Marcela Fertier, sekretarza płk. André Halliera, byłego attaché wojskowego w Budapeszcie, Paryż, 10 VI 1948 r.

42 Ibidem, Wyciąg z rejestru ślubów w Budapeszcie (kopia tłumaczenia na język francuski [HT 73302]), 1 VII 1947 r., załącznik nr 8 do Memoriału Charles'a Heroza z 20 III 1948 r., Memoire à l'attention de Monsieur le Ministre de la Justice, faisant suite à mes lettres du: 27 janvier, 18 février et 2 mars 1948, relatives à la procédure d'extradution de mon épouse Marthe Heroz, née Puretz, Charles Heroz, Saint Denis, 20 mars 1948, 13 pièces jointes, numérotées de 1 à 13.

${ }^{43}$ Ibidem, Copie de ma déposition faite au $2^{\text {ème }}$ Tribunal Militaire Permanent à Paris en Mars 1947, Zeznanie Charles'a Heroza, Saint Denis, 30 I 1947 r. wraz z listą świadków jego aktywności na Węgrzech. 
W tym czasie znowu ujawnił się Stanisław Faber. Już w lutym złożył donos na Charles'a Heroza do Komitetu de Gaulle’a w Budapeszcie, który zastąpił Legację francuską. Padły w tym piśmie ciężkie oskarżenia pod adresem Marty przede wszystkim, ale i Charles'a Heroza.

Marta miała donosić na Gestapo na Żydów w Polsce i na Węgrzech, doprowadzić do aresztowania, deportacji i śmierci wielu osób. Z pisma Fabera wynika, że akt małżeństwa Marty z Charles’em Herozem był nieprawdziwy, chodziło bowiem tylko o to, by pomóc jej opuścić Budapeszt i wymknąć się sprawiedliwości. Zgodnie z wymogami procedury małżonkowie zostali przesłuchani przez sąd wojskowy w Turze, lecz nie dopatrzono się niczego, co potwierdziłoby oskarżenia. Strona francuska nie nadała sprawie dalszego biegu, a materiały ze śledztwa zostały już po powrocie do Francji złożone w Marsylii w dziale ochrony wojskowej ${ }^{44}$.

Sfrustrowany Faber nie dawał za wygraną. 15 kwietna, w chwili wyjazdu Herozów do Francji, pojawił się w otoczeniu rodziny w obozie w Tura i oskarżył Martę przed dowództwem rosyjskim, że to ona sprowokowała jego aresztowanie w Budapeszcie. Po czym Faber i jego bliscy opuścili obóz, pozostawiając fałszywy adres. Marta została aresztowana przez NKWD. Rosjanie przekazali ją węgierskiej policji politycznej w Budapeszcie. Charles Heroz nie wyjechał do Francji, by nie opuszczać żony. Policja podczas 3 miesięcy prowadziła drobiazgowe śledztwo w środowisku polskim, węgierskim i francuskim. Początkowo Marta mieszkała w prywatnym mieszkaniu przy ul. Szentkiralyi 26, lecz od 23 maja przebywała już w areszcie śledczym z zarzutem popełnienia zbrodni wojennej. Po przesłuchaniach, których blizny nosiła jeszcze długo, 23 lipca 1945 r. stanęła przed węgierskim Trybunałem Ludowym (Nepbirosag). Jej wyczerpująca wypowiedź na temat egzystencji w Polsce i na Węgrzech oraz zeznania świadków obaliły zgromadzone dowody. Sąd uznał bezpodstawność oskarżenia i Marta została uniewinniona ${ }^{45}$. Faber się nie stawił, by podtrzymać zasadność swoich oskarżeń. Uciekł z rodziną i stał się obiektem poszukiwań węgierskiej policji.

7 sierpnia 1945 r. Charles i Marta znaleźli się we Francji u jego rodziców w Besançon. Marta miała paszport wydany jej przez Legację francuską w Pradze na swoje nazwisko panieńskie. Rychło po powrocie Charles wyjechał jako ochotnik do Indochin, gdzie brał udział w operacjach wojennych aż do czerwca $1946 \mathrm{r}$. Marta została u teściów i szybko podjęła pracę w fabryce. Otrzymała dowód oso-

${ }^{44}$ Ibidem, Poświadczenie oficera rezerwy Michela Legendre, który prowadził przesłuchanie w obozie w Tura, Paryż, 19 III 1948 r., załącznik nr 5 do Memoriału Charles'a Heroza z 20 III 1948 r., Memoire à l'attention de Monsieur le Ministre de la Justice, faisant suite à mes lettres du: 27 janvier, 18 février et 2 mars 1948, relatives à la procédure d'extradution de mon épouse Marthe Heroz, née Puretz, Charles Heroz, Saint Denis, 20 mars 1948, 13 pièces jointes, numérotées de 1 à 13.

${ }^{45}$ Ibidem, Wyrok Trybunału w Budapeszcie, nr nb.V.1610/1945/2, z 23 VII 1945 r. z dopiskiem: „Wyrok jest definitywny” (kopia tłumaczenia wyroku na język francuski potwierdzona w kwietniu 1947 r. [FB 08630] oraz 26 II 1948 r. [ZM 19511]). 
bisty cudzoziemca, prawomocny do końca października $1947 \mathrm{r}^{46} \mathrm{~W}$ Besançon dosięgła ją najszczęśliwsza wiadomość - matka przeżyła Auschwitz i wróciła do Krakowa ${ }^{47}$. Z początkiem 1946 r. Marta złożyła w Besançon prośbę o nadanie obywatelstwa francuskiego, a w kwietniu udała się do Paryża, aby załatwić sprawę jej ewentualnego wyjazdu do Indochin. Tymczasem Charles został ranny i ze względu na ciężki stan zdrowia zwolniony ze służby. Przyznano mu rentę inwalidzką. Chciał, aby osiedli na stałe w Paryżu, Marta zatem wynajęła mieszkanie w Saint Denis i znalazła pracę w fabryce. Charles wrócił z Indochin 3 lipca $1946 \mathrm{r}$. Wszystko zapowiadało dalsze szczęśliwe życie małżonków, gdyby nie to, że w Krakowie pojawił się uciekinier z Węgier - Stanisław Faber.

\section{W pętli oskarżeń. Zbrodniarka wojenna?}

Po wojnie kolaboracja Żydów w okupowanej Europie była poruszana w kontekście rozliczeń ich postawy w gettach, w niemieckich obozach pracy i zagłady oraz w ośrodkach dla displaced persons. Kolaboranci żydowscy byli ścigani w różnych krajach i niekiedy stawiani przed sądem, lecz karano ich stosunkowo łagodnie, sami byli bowiem ofiarami nazizmu. Byli współpracownikami Niemców, lecz nie bezpośrednimi sprawcami zbrodni. W czasie wojny polski ruch oporu nie interweniował w sprawy wewnętrzne Żydów, lecz likwidował tych kolaborantów, którzy - jego zdaniem - swoim działaniem szkodzili polskiemu podziemiu ${ }^{48}$. W 1944 r. z Krakowa udało się przedostać na Węgry kilku konfidentom, a wśród nich powszechnie znanej Stefani Brandstätter, która po utworzeniu getta została po aryjskiej stronie. I właśnie nazwiska jej oraz Marty Puretz w listopadzie 1946 r. znalazły się razem w aktach Głównej Komisji Badania Zbrodni Niemieckich jako osób poszukiwanych, które winny zostać osądzone w Polsce ${ }^{49}$.

Dlaczego Marta Puretz? Kluczem do zrozumienia tego faktu jest osoba Fabera - Stanisława alias Mariana. W Budapeszcie mieliśmy do czynienia ze Stanisławem. Pod tym imieniem przygarnął Martę po ucieczcie z obozu Magdolna, załatwił jej nielegalne papiery na nazwisko Maria Wolanecka, wygrażał telefonicznie - obiecując zemstę - Charles'owi Herozowi, z którym się związała, zadenuncjował ich w Komitecie de Gaulle’a w Budapeszcie i wreszcie dopadł w obozie w Tura, gdzie oskarżył Martę przed NKWD, że była agentką Gestapo.

\footnotetext{
${ }^{46}$ Ibidem, L' Inspecteur de Sûreté Libis à Monsieur le Commissaire de Police du $2^{\mathrm{e}}$ arrondissement, Besançon, 17 IV 1946 r. (kopia raportu z dochodzenia policyjnego dotyczącego Marty Puretz).

${ }^{47}$ Rena Puretz przeszła przez pięć obozów i podobozów: Płaszów, Auschwitz, Ravensbrück, Gundelsdorf i Rechlin, 1 V 1945 r. została wyzwolona przez Armię Czerwoną, wróciła do Krakowa i zamieszkała przy ul. Różanej 15 u Marii Feliksiak (AN, 19910593/7, Oświadczenie: Aleksander Appel i Marianna Feliksiak, Kraków 19 III 1948 r. (tekst polski i tłumaczenie francuskie).

${ }^{48}$ Mędykowski, Przeciw swoim..., s. 219.

${ }^{49}$ AIPN, 164/4979, Akta w sprawie 1) Puretz Marta, 2) Brandstätter Stefania.
} 
Doprowadził w ten sposób do jej uwięzienia i postawienia przed węgierskim Trybunałem Ludowym, który później uwolnił ją ze wszystkich oskarżeń.

W Polsce od pewnego momentu Faber występował pod imieniem Marian. Był oskarżycielem, a jednocześnie głównym świadkiem oskarżenia Marty Puretz o współpracę z Gestapo w Krakowie i w Budapeszcie. Stał u początku wpisania jej na listę zbrodniarzy wojennych. W 1945 r. wrócił do Krakowa i jako Marian Faber złożył 30 lipca pierwsze zeznanie w Wojewódzkim Urzędzie Bezpieczeństwa Publicznego ${ }^{50}$.

To, że Faber - Stanisław alias Marian - był jedną i tą samą osobą, w niepodważalny sposób potwierdziła Eva Stapp w liście do Marty. Ewa, która dzieliła z Martą i Faberem mieszkanie w Budapeszcie, w 1945 r. spotkała go przypadkowo w Krakowie. „Był taki jak zawsze - brudny, obrzydliwy i tylko wstyd mi było z takim oberwańcem stać na Plantach" - pisała do Marty, do Paryża, w marcu 1948 r. Pocieszając ją, że nikt nie może polegać na oskarżeniach jednego człowieka, dodała jednak: „W każdym razie takie typy jak Tuman są do wszystkiego zdolne..."51. Kto jak kto, ale Eva Stapp nie mogła mieć żadnych wątpliwości, kogo spotkała w Krakowie. W Budapeszcie tumanem nazywały właśnie Stanisława Fabera.

Drugą osobą, która mówiąc o Faberze, użyła imienia Stanisław, był Józef Puretz. Przeżył wojnę, wrócił do Krakowa, skąd później wyjechał do Paryża. W 1948 r. złożył tam oświadczenie, w którym przedstawił szczegóły z powojennego okresu w rodzinnym mieście. Po pierwsze, zostało wówczas przeciwko Marcie Heroz wszczęte dochodzenie przez Komitet Izraelicki ${ }^{52}$ z Krakowa z oskarżenia Stanisława Fabera, uciekiniera z Węgier. Po drugie, Faber rozpoczął bardzo aktywną działalność w środowisku krakowskim przeciwko Marcie, aby stworzyć sprzyjający klimat dla wszczętego śledztwa - rozpowszechniał wiadomości o jej współpracy z Gestapo, zamieszczał ogłoszenia o tym w gazetach i na afiszach. Korzystając z wpływów w mieście, wywarł presję na pracodawców Reny Puretz, aby zwolnili ją z pracy. Wielokrotnie groził jej samej oraz Marii Feliksiak i Salomei Feliksik, które broniły dobrego imienia Marty. Józef Puretz uważał, że wpływy Fabera wynikały z jego pozycji w środowisku politycznym Krakowa ${ }^{53}$.

${ }^{50}$ AIPN Kr, 010/6637, Protokół przesłuchania Mariana Fabera, WUBP, Kraków, 30 VII 1945 r.

${ }^{51}$ AN, 19910593/7, List Ewy Stapp do Herozów, Warszawa, 1 III 1948 r. Jest też tłumaczenie francuskiej części listu dotyczącej Fabera (ibidem, Załącznik 1 do Memoriału Charles'a Heroza z 20 III 1948 r., Memoire à l'attention de Monsieur le Ministre de la Justice, faisant suite à mes lettres du: 27 janvier, 18 février et 2 mars 1948, relatives à la procédure d'extradution de mon épouse Marthe Heroz, née Puretz, Charles Heroz, Saint Denis, 20 mars 1948, 13 pièces jointes, numérotées de 1 à 13 ).

${ }^{52}$ Prawdopodobnie chodzi o Wojewódzki Komitet Żydowski.

${ }^{53}$ AN, 19910593/7, Oświadczenie Józefa Puretza w języku francuskim, 8 III 1848 r., Załącznik 12 do Memoriału Charles'a Heroza z 20 III 1948 r., Memoire à l'attention de Monsieur le Ministre de la Justice, faisant suite à mes lettres du: 27 janvier, 18 février et 2 mars 1948, 
Sam Faber osobiście doglądał sprawy oskarżenia, aby przyśpieszyć bieg wydarzeń. Już w marcu 1946 r. pojawił się w konsulacie francuskim w Krakowie, gdzie przedstawił się - co znamienne - jako „delegat Komisji polskiej do badania zbrodni wojennych: Stanisław Faber, zamieszkały w Krakowie, ul. Starowiślna 54/6". Poinformował konsula o zbrodniczej działalności Marty, która używając fałszywych dokumentów, zawarła ślub z podoficerem francuskim Charles'em Herozem $^{54}$. Gdy w maju 1946 r. Okręgowa Komisja Badania Zbrodni Niemieckich w Krakowie, nie miała jeszcze żadnych informacji na temat Stefanii Brandstätter i Marty Puretz, Faber pojawił się w biurze Komisji z informacją, że Marta przebywa we Francji. Był żywo zainteresowany wynikiem dochodzenia, robił wrażenie, że trafił już do odpowiednich urzędów wyższego szczebla, by nadać bieg tej sprawie ${ }^{55}$.

Od kwietnia 1946 r. zaczęło się kompletowanie dokumentów przez krakowski Urząd Bezpieczeństwa Publicznego. Zostały wezwane na przesłuchanie Maria Feliksiak i Rena Puretz ${ }^{56}$. Ich zeznania nie obciążały Marty - zostały zatem pominięte $w$ dalszych procedurach. W maju zeznawały Elżbieta Jasińska ${ }^{57}$, która załatwiała w podziemiu fałszywą kenkartę dla Marty, oraz jej siostra Maria Ko$ł^{\prime a c z}{ }^{58}$. Po raz drugi był przesłuchiwany główny świadek Marian Faber. Choć jego zeznania różniły się w szczegółach, oskarżenia pod adresem Marty były porażające. Wyłaniała się z nich perfidna i chciwa osoba, a jednocześnie sumienna agentka Gestapo. Po wejściu Niemców do Budapesztu pod swoim nazwiskiem zgłosiła się do znanych jej z Krakowa gestapowców - Ericha Vollbrechta i Franza Stiecha. Zajmowała się identyfikacją Żydów na ulicy. Asystowała podczas aresztowań i rewizji. Sporządzała raporty, podpisywała je pseudonimem „Marija”, a zdaniem polskiej tłumaczki w Wiedniu, cieszyła się opinią jednego z najlepszych współpracowników Gestapo. Kiedy Marian Faber padł ofiarą Weiningera, konfidenta z Krakowa, i został aresztowany, członkowie rodziny - szukając protekcji, by dotrzeć do Gestapo - korzystali z obficie opłacanych usług Marty Puretz. Wszyscy oni zostali przez nią wydani i zesłani do Auschwitz. Tylko Marianowi Faberowi udało się zbiec z więzienia w Budapeszcie i ukrywał się aż do wejścia Armii Czerwonej. Po czym odnalazł Martę Puretz w obozie w Tura i oddał ją w ręce NKWD, nim zdołała uciec do Francji. Podczas przesłuchania

relatives à la procédure d'extradution de mon épouse Marthe Heroz, née Puretz, Charles Heroz, Saint Denis, 20 mars 1948, 13 pièces jointes, numérotées de 1 à 13.

${ }^{54}$ Ibidem, Le consul de France à Cracovie à Monsieur le Prefet du Département du Doubs (Besançon), Cracovie, 22 III 1946 r. (prośba o przeprowadzenie śledztwa w spawie Marty Puretz).

${ }^{55}$ AIPN, 174/29, Okręgowa Komisja Badania Zbrodni Niemieckich w Polsce do Prokuratury Specjalnego Sądu Karnego w Krakowie, Kraków, 20 V 1946 r.

${ }^{56}$ AIPN Kr, 010/6637, Protokół przesłuchania Marii Feliksiak, WUBP, Kraków, 4 IV 1946 r.; ibidem, Protokół przełuchania Reny Puretz, WUBP, Kraków, 3 IV 1946 r.

${ }^{57}$ Ibidem, Protokół przesłuchania Elżbiety Jasińskiej, WUBP, Kraków, 16 V 1946 r.

${ }^{58}$ Ibidem, Protokół przesłuchania Marii Kołacz, WUBP, Kraków, 16 V 1946 r. 
przez NKWD przyznała się do współpracy z Gestapo i została odesłana do Polski. Z transportu udało jej się zbiec ${ }^{59}$.

Ten bezmiar oszczerstw został wzbogacony o kolejne wymysły, nowe w porównaniu z jego doniesieniami do Komitetu de Gaulle'a w Budapeszcie i do NKWD w obozie w Tura. Jest zastanawiające, czy tylko wchodziła w grę obsesyjna zazdrość porzuconego mężczyzny, czy może coś więcej - wyprzedzająca obrona przez atak.

W kwietniu 1948 r. Rena Puretz zeznała w konsulacie francuskim w Krakowie, iż sądziła, że córka była zaręczona z Faberem, choć nie mogła tego potwierdzić. „To Faber, według mnie, miał związek z Niemcami, ponieważ obiecał mnie uwolnić" - oświadczyła à propos 2 tys. zł, których domagał się od Marty w Budapeszcie na wydobycie matki z obozu płaszowskiego ${ }^{60}$. Eva Stapp zaś, przypominając Marcie pobyt na Węgrzech, pisała: „Jeżeli chodzi o mnie, to mogę zawsze powiedzieć to, co wiesz, że w Budapeszcie bałaś się i ukrywałaś od chwili wkroczenia Niemców, a w ciemnych sprawach Tumana też coś niecoś mogę opowiedzieć [...]. On był taki szuja, że był zdolny do wszystkich najbardziej brudnych i obrzydliwych rzeczy”. Dodała przy tym znamienną uwagę: „W każdym razie takie typy jak Tuman są do wszystkiego zdolne, tak on jest i jego brat, może równie dobrze mógł pracować dla Gestapo dla ratowania swojej skóry"61. Wynikają z tego dwie informacje - wiadomość pewna, że „Tuman”, czyli Stanisław Faber miał brata, oraz podejrzenie, że zarówno on, jak i nieznany z imienia brat mogli pracować dla Gestapo.

Najbardziej zdumiewający był tekst oskarżenia Marty Heroz z domu Puretz, przedłożony przez prokuratora w węgierskim Trybunale Ludowym w Budapeszcie 30 czerwca 1945 r. ${ }^{62}$ Oprócz znanych frazesów o wydawaniu Gestapo Żydów i partyzantów w Polsce oraz Żydów uciekających z Węgier do Rumuni, jest wręcz nieprawdopodobny fragment dotyczący Fabera: „W maju 1944 r. poślubiła Stanisława Fabera, również żyda, narodowości polskiej, który, podobnie jak ona, pozostawał w związku z Gestapo za pośrednictwem urzędnika tej organizacji, o nazwisku Stich [sic!]”63. „W końcu, w miesiącu czerwcu 1944 r., pomogła Ge-

${ }^{59}$ Ibidem, Protokół przesłuchania Mariana Fabera, WUBP, Kraków, 15 V 1946 r.

${ }^{60}$ AN, 19910593/7, Déclaration de Mme Puretz Rena, dom. à Cracovie, 15, rue Rozana au sujet de Mme Marta Heroz, née Puretz (kopia tłumaczenia na język francuski), Kraków, 19 IV $1948 \mathrm{r}$.

${ }^{61}$ Ibidem, List Ewy Stapp do Herozów, Warszawa, 1 III 1948 r., załącznik 1 do Memoriału Charles'a Heroza z 20 III 1948 r., Memoire à l'attention de Monsieur le Ministre de la Justice, faisant suite à mes lettres du: 27 janvier, 18 février et 2 mars 1948, relatives à la procédure d'extradution de mon épouse Marthe Heroz, née Puretz, Charles Heroz, Saint Denis, 20 mars 1948, 13 pièces jointes, numérotées de 1 à 13.

${ }^{62}$ Ibidem, Kopia tłumaczenia na język francuski, nr 711, 1 IV 1948 r. [KE 15493] [w korespondencji Charles'a Heroza z ministrem sprawiedliwości z 3 IV 1948 r. stanowiącej uzupełnienie Memoriału z 20 III 1948 r.].

${ }^{63}$ Gestapowiec miał na nazwisko Stiech. 
stapo w aresztowaniu członków rodziny Stanisława Fabera". To oskarżenie było sformułowane na podstawie zeznania Fabera, złożonego przed NKWD w obozie w Tura. Pytanie, pod jakim imieniem złożył je Faber? Zaślepiony nienawiścią do Marty, oskarżając ją o współpracę z Gestapo, dla uwiarygodnienia jej winy dodał jeszcze własną - współpracę konfidenta Stanisława ze Stiechem ${ }^{64}$. To zapewne dlatego po uniewinniającym procesie Marty Faber wraz z rodziną był ścigany przez policję węgierską. W momencie ucieczki z Węgier do Polski nie przypuszczał, aby te informacje dotarły do kraju. Mógł tak sądzić przez pewien czas, skoro używał imienia Stanisław, lecz później - z obawy o siebie - zdecydował się na zmianę tożsamości: imienia (Marian), daty i miejsca urodzenia (1900, $1905 \mathrm{oraz}$ Biłgoraj, Bochnia), a nawet wyznania (dwie różne wersje w zeznaniach: „religia mojżeszowa”, „bez wyznania” ${ }^{65}$. Tylko adres zamieszkania zawsze pozostawał ten sam - Kraków, ul. Starowiślna 54/6.

W oskarżeniu prokuratora węgierskiego znalazla się informacja o ślubie Stanisława z Martą. Jeśli nie uzna się tego za konfabulacje Fabera, to można się zastanowić, czy aby nie przymusił uzależnionej od niego dziewczyny do ślubu religijnego, o którym nikt nie wiedział. To mogło tłumaczyć dziką wściekłość, z jaką oskarżał Charles'a Heroza o to, że zawarł małżeństwo z Martą nielegalnie. Ciekawe, że w 1946 r. jeden z francuskich urzędników dziwił się, że Herozowie po ślubie cywilnym nie wzięli ślubu religijnego ${ }^{66}$. Czyżby były przeszkody? A może po prostu obojgu, zeświecczonym Żydom, nie zależało na ślubie pod chupą?

21 czerwca 1946 r. Specjalny Sąd Karny w Krakowie, na podstawie zeznań trzech świadków - Mariana Fabera, Elżbiety Jasińskiej i Marii Kołacz - oraz informacji Bolesława, męża Elżbiety Jasińskiej, postanowił zastosować wobec Marty Puretz tymczasowe aresztowanie ${ }^{67}$. Podobną decyzję podjęto w sprawie Stefanii Brandstätter. W ślad za tym 28 czerwca został wysłany za Martą list gończy ${ }^{68}$. Zarzucane przestępstwo wynikało z art. 1 dekretu PKWN z 31 sierpnia 1944 r., w brzmieniu dekretu z 16 lutego 1945 r. „o wymiarze kary dla faszystowsko-hitlerowskich zbrodniarzy [...] oraz dla zdrajców Narodu Polskiego". Przestępstwo

${ }^{64}$ Przypisał jej zarzuty, z których jego samego dobrze znano w Budapeszcie - nikczemne interesy, w które były zaangażowane pieniądze polskiego i szwedzkiego komitetu żydowskiego, uzyskiwane ze Szwecji, aby wspomagać uciekinierów udających się do Rumunii.

${ }^{65}$ Por. AIPN Kr, 010/6637, Protokół przesłuchania Mariana Fabera, WUBP, Kraków, 30 VII 1945 r.; ibidem, Protokół przesłuchania Mariana Fabera, WUBP, Kraków, 15 V 1946 r.

${ }^{66} \mathrm{AN}, 19910593 / 7$, L' Inspecteur de Sûreté Libis à Monsieur le Commissaire de Police du $2^{\mathrm{e}}$ arrondissement, Besançon, 17 IV 1946 r. (kopia raportu z dochodzenia policyjnego dotyczącego Marty Puretz).

${ }^{67}$ Ibidem, Wyciąg z protokołu wspólnego posiedzenia niejawnego sądu specjalnego, 1374/46, Kraków, 21 VI 1946 r. (tekst polski wraz z tłumaczeniem dokumentu na język francuski).

${ }^{68}$ Ibidem, Prokuratura Specjalnego Sądu Karnego w Krakowie, List gończy: Puretz Marta vel Maria Wolanecka vel Marta Heroz, Kraków, 28 VI 1946 r. (tekst polski wraz z tłumaczeniem na język francuski). 
podlegało karze śmierci ${ }^{69}$. W liście gończym zapowiadano żądanie ekstradycji Puretz z Francji.

Już wcześniej ruszyła cała machina urzędnicza. Od 15 maja 1946 r. rozpoczęła się korespondencja między Prokuraturą Specjalnego Sądu Karnego w Krakowie a Okręgową Komisją Badania Zbrodni Niemieckich w Krakowie, w sprawie materiałów „dotyczących zbrodniczej działalności konfidentek krakowskiego Gestapo Stefy Brandstätter i Marty Puretz" ${ }^{\prime 70}$. W tym samym czasie krakowski Urząd Bezpieczeństwa Publicznego zwrócił się do konsulatu francuskiego z prośbą o „spowodowanie aresztu prewencyjnego" w stosunku do Marty Puretz, podając jej adres zamieszkania: Besançon, rue Clemenceau $8^{71}$. Po wymianie korespondencji konsula z Paryżem odpowiedź nadeszła z początkiem września. Francuskie władze sądownicze mogą interweniować w sprawie Marty Puretz, żony Charles'a Heroza, jedynie w wypadku, gdy rząd Polski zwróci się z oficjalną prośbą o ekstradycję do rządu francuskiego ${ }^{72}$.

Jesienią rozgrywała się już batalia w Londynie o „wciągnięcie na międzynarodową listę zbrodniarzy wojennych" Marty Puretz i Stefanii Brandstätter ${ }^{73}$. Sprawą zajmował się dr Mieczysław Szerer, Delegat Polski do Międzynarodowej Komisji Badania Zbrodni Wojennych, która urzędowała w Londynie. 8 listopada 1946 r. napłynęło doń oficjalne pismo z zawiadomieniem, że stosownie do jego prośby Marta Puretz i Stefania Brandstätter zostały umieszczone na liście zbrodniarzy wojennych ${ }^{74}$. Szerer przesłał je do ambasadora polskiego w Paryżu jako dowód wzmacniający prośbę o przeprowadzenie ekstradycji Marty Puretz do Polski ${ }^{75}$.

Strona francuska zachowywała dużą dozę nieufności wobec postulatu ekstradycji oskarżonej. Po pierwsze, francuskie Ministerstwo Spraw Zagranicznych do końca $1947 \mathrm{r}$. nie otrzymało od władz polskich oficjalnej prośby o ekstradycję z jednoczesnym dostarczeniem dokumentów dowodowych oskarżeń ${ }^{76}$. Po

${ }^{69}$ Ibidem, Dekret Polskiego Komitetu Wyzwolenia Narodowego z 31 III 1944 r. (tekst polski wraz z tłumaczeniem na język francuski).

${ }^{70}$ AIPN, 174/29, Wiceprokurator J. Jasiński do Okręgowej Komisji Badania Zbrodni Niemieckich, Kraków, 15 V 1945 r.

${ }^{71}$ AIPN Kr, 010 6637, WUBP w Krakowie do Konsulatu Republiki Francuskiej, Kraków, $17 \mathrm{~V} 1946 \mathrm{r}$.

${ }^{72}$ Ibidem, Konsul francuski do komendanta WUBP, Kraków, 4 IX 1946 r.

${ }^{73}$ AIPN, 164/4779, Ministerstwo Sprawiedliwości do Mieczysława Szerera, sędziego Sądu Najwyższego i delegata Polski do Międzynarodowej Komisji Badania Zbrodni Wojennych w Londynie (Ambasada Polska), Warszawa, 18 IX 1946 r.; ibidem, Ministerstwo Spraw Zagranicznych do Ambasady RP w Londynie, Warszawa, 27 IX 1946 r.

${ }^{74}$ AIPN, 164/4779, United Nations War Crimes Commission do dr. Mieczysława Szerera, Londyn, 8 XI $1946 \mathrm{r}$.

${ }^{75}$ Ibidem, Delegat rządu do Międzynarodowej Komisji Zbrodni Wojennych do Ambasadora RP, Londyn, 18 XI 1946 r.

${ }^{76}$ AN, 19910593/7, Ministère de la Justice, Direction Criminelle, $3^{\circ}$ Bureau, № 3447 T.4, Note pour Monsieur le Garde des Sceaux, 15 IV 1948 r. 
drugie, już wcześniej chargé d'affaires w Warszawie zlecił zebranie informacji o oskarżonej podczas jej pobytu w Krakowie ${ }^{77}$. W kwietniu 1947 r. w konsulacie zeznawały Rena Puretz, Maria Feliksiak i Salomea Feliksik ${ }^{78}$. Informacje uzyskane od nich były sprzeczne z oskarżeniami strony polskiej. We Francji zaś Marta i jej mąż złożyli wyczerpujące zeznania przed Stałym Trybunałem Wojskowym w Paryżu odnośnie do jej pobytu w Polsce i na Węgrzech ${ }^{79}$. Udokumentowane były dołączonymi spisami osób, które mogły potwierdzić jej działania w Krakowie, a także tych, którzy ją ukrywali po ucieczce z getta ${ }^{80}$. Puretz dołączyła też listę osób, które ukrywały ją lub pomagały jej na Węgrzech i mogły zaświadczyć o jej postępowaniu ${ }^{81}$. Marta oświadczyła, że Faber to jej były narzeczony, który z zemsty ściga ją oszczerczymi doniesieniami. W maju 1947 r. Trybunał Wojskowy umorzył wobec niej postępowanie ${ }^{82}$.

Sprawa Marty Puretz długo jeszcze zajmowała kilka francuskich ministerstw: sprawiedliwości, spraw wewnętrznych, sił zbrojnych i spraw zagranicznych. W latach 1946-1951 krążyła między nimi bogata korespondencja. Francuzi osobiście sprawdzili w Londynie wpis nazwiska Puretz na listę Komisji Narodów Zjednoczonych. Figurowała wśród zbrodniarzy wojennych na liście nr 45, pod nr 455, zapisana - co ciekawe - jako obywatelka narodowości niemieckiej, pracująca jako tajny agent Gestapo w Krakowie i Budapeszcie ${ }^{83}$. Wobec wagi zarzutów strona francuska była już skłonna przychylić się do ekstradycji, tym bardziej że zgodna była z duchem i literą Deklaracji londyńskiej z 13 stycznia 1942 r., przyjętej przez aliantów w kwestii ścigania zbrodniarzy wojennych ${ }^{84}$.

${ }^{77}$ Ibidem. Potwierdzenie tego faktu znajduje się w korespondencji między ministrem sprawiedliwości a ministrem spraw wewnętrznych z 17 III $1948 \mathrm{r}$.

${ }^{78}$ Ibidem, Consulat de France à Cracovie, 19 IV 1948 r., Pismo do Ministerstwa Spraw Zagranicznych wraz z kopiami zeznań Reny Puretz, Marii Feliksiak i Salomei Feliksik.

${ }^{79}$ Ibidem, Copie de ma déposition faite au 2 ème Tribunal Militaire Permanent à Paris en Mars 1947, Zeznanie Charles'a Heroza, Saint Denis, 30 I 1947 r. wraz z listą świadków jego aktywności na Węgrzech; ibidem, Ma déposition faite au $2^{\text {ème }}$ Tribunal Militaire Permanent en Mars 1947, Zeznanie Marthe Heroz, Saint Denis, 30 I 1947 r. wraz z załącznikami.

${ }^{80}$ Spisy osób w Aneksie, Lista nr 1.

${ }^{81}$ Spisy osób w Aneksie, Lista nr 2.

${ }^{82}$ AN, 19910593/7, 2e Tribunal Militaire Permanent de Paris, Ordonnnance de Non-Lieu, 8 V 1947 r., nr 2967B, załącznik 13 do Memoriału Charles'a Heroza z 20 III 1948 r., Memoire à l'attention de Monsieur le Ministre de la Justice, faisant suite à mes lettres du: 27 janvier, 18 février et 2 mars 1948, relatives à la procédure d'extradution de mon épouse Marthe Heroz, née Puretz, Charles Heroz, Saint Denis, 20 mars 1948, 13 pièces jointes, numérotées de 1 à 13. Trybunał umorzył postępowanie, ponieważ zgodnie art. 66 kodeksu sądownictwa wojskowego zarzuty stawiane Marcie Puretz nie nosiły znamion czynu zagrażającego bezpieczeństwu Francji,

${ }^{83}$ Ibidem, Ministère de la Justice, Direction du Service de Recherches de Crimes de guerre, Note pour M. Le directeur de Affaires Criminelles- $3^{\text {ème }}$ Bureau, Paris, 29 XII 1947 r.

${ }^{84}$ Ibidem, Le Ministre des Forces Armées à Monsieur le Garde des Sceaux, Ministre de la Justice, Paris, 9 I 1948 r. 
Tymczasem w 1948 r. wciąż niezałatwiona sprawa naturalizacji Marty zaalarmowała małżonków, nieświadomych do tego czasu dramatyzmu sytuacji. W marcu Charles Heroz dowiedział się o wszczętej procedurze ekstradycji, osobiście zebrał zeznania świadków przebywających poza Polską - we Francji, w Wielkiej Brytanii, na terenie Niemiec - które poświadczały niewinność żony ${ }^{85}$, i dostarczył je jako załączniki do korespondencji z ministerstwem sprawiedliwości. Kilkakrotnie pisał i prosił o posłuchanie ministra ${ }^{86}$, jednocześnie angażując w sprawie żony wpływowego deputowanego ${ }^{87}$. W efekcie Marta Puretz nigdy nie została aresztowana we Francji.

Strona polska kilkakrotnie domagała się wydania Puretz ${ }^{88}$. Dopiero jednak w marcu 1948 r. dostarczyła dokumenty dowodowe oskarżenia Marty Puretz, po polsku i w tłumaczeniu na język francuski. Były to: Wyciąg z protokołu wspólnego posiedzenia niejawnego Specjalnego Sądu Karnego w Krakowie z 21 czerwca 1946 r., zeznania trzech świadków oraz Dekret PKWN z 31 sierpnia 1944 r., w brzmieniu dekretu z 16 lutego $1945 \mathrm{r}^{89}$

Marta Puretz nie została deportowana. Minister sprawiedliwości Francji wyjaśnił tę sytuację następująco: „Po dochodzeniu, równie drobiazgowym co możliwym do przeprowadzenia, zdecydowaliśmy z kolegą z ministerstwa spraw

${ }^{85}$ Ibidem, Charles Heroz do ministra sprawiedliwości, Saint Denis, 16 VI 1948 r., załączniki do dokumentu: Attestation, Hazai Béla, Paris, 10 V 1948 r.; Attestation, Marcel Fertier, Paris, 10 VI 1948 r.; Déclaration, Gisèle Fendler, Londres, 21 IV 1948 r.; Déclaration solonnelle sans serment, Bluma Preis, Planegg, 26 V 1948 r.

${ }^{86}$ Ibidem, Charles Heroz do ministra spraw wewnętrznych, Saint Denis, 27 I 1948 r.; ibidem, Charles Heroz do ministra sprawiedliwości, Saint Denis, 18 II 1948 r.; ibidem, Memoire à l'attention de Monsieur le Ministre de la Justice, faisant suite à mes lettres du: 27 janvier, 18 février et 2 mars 1948, relatives à la procédure d'extradution de mon épouse Marthe Heroz, née Puretz, Charles Heroz, Saint Denis, 20 mars 1948; ibidem, Charles Heroz do ministra sprawiedliwości, Sant Denis, 16 VI $1948 \mathrm{r}$.

${ }^{87}$ Korespondencja w tej sprawie: ibidem, List Charles'a Heroza do André Muttera, Saint Denis, 19 II 1948 r.; ibidem, André Mutter, député de l'Aube do Ministre de la Justice, Direction des Affaires Criminelles, Contentieux, des Affaires Etrangères, Paris, 9 III 1948 r.; ibidem, Ministère de la Justice, Direction Criminelle, $3^{\circ}$ Bureau do André Muttera, 27 IV 1948 r.; ibidem, Ministère de la Justice, Direction Criminelle, $3^{\circ}$ Bureau do André Muttera, 12 VI 1948 r.; ibidem, Ministère de la Justice, Direction Criminelle, $3^{\circ}$ Bureau do André Muttera, 15 VI 1948 r. Ostatni dokument zawiera informację, że Marta Puretz nie zostanie poddana ekstradycji do Polski: „j'ai l'honneur de vous faire connaitre qu'après examen approfondi des circonstances de cette affaire il a été décidé de ne pas accéder à la demande des autorités polonaises".

${ }^{88}$ Ibidem, Nota ambasady polskiej do francuskiego ministerstwa spraw zagranicznych, 12 XI 1946 r.; ibidem, Nota ambasady polskiej do francuskiego ministerstwa spraw zagranicznych, 21 XI 1947 r.; ibidem, Nota ambasady polskiej do francuskiego ministerstwa spraw zagranicznych, 10 II 1948 r.; ibidem, Nota ambasady polskiej do francuskiego ministerstwa spraw zagranicznych, 20 X 1950 r.; ibidem, Nota ambasady polskiej do francuskiego ministerstwa spraw zagranicznych, 19 X $1951 \mathrm{r}$.

${ }^{89}$ Ibidem, Nota ambasady polskiej do francuskiego ministerstwa spraw zagranicznych, 10 III $1948 \mathrm{r}$. 
zagranicznych, że nie spełnimy prośby Rządu pozywającego" ${ }^{\prime 0}$. Dossier zgromadzone $\mathrm{w}$ jej sprawie, szczególnie dochodzenie przeprowadzone przez konsula w Krakowie, nie wskazywały w niewątpliwy sposób na winę Puretz. Pozostawała kwestia prawnego umotywowania odmowy ekstradycji oskarżonej ${ }^{91}$. Nie przeprowadzono jej deportacji do Polski $\mathrm{z}$ dwu powodów. Po pierwsze, $\mathrm{w}$ myśl zasady res judicata, że nie sądzi się ponownie za sprawę, w której oskarżona została już raz uniewinniona przez sąd budapeszteński. Po drugie, zgodnie z art. 9 traktatu ekstradycyjnego francusko-polskiego z 30 grudnia 1925 r., strona polska nie dostarczyła w ciągu wymaganych 5 tygodni materiałów dowodowych ${ }^{92}$. Francja w oficjalnej nocie z 29 czerwca 1948 r. odmówiła ekstradycji Marty Puretz $^{93}$, co wywołało dalsze kroki dyplomacji polskiej.

Warszawa utrzymywała, że trybunał węgierski uniewinnił Puretz z braku przestępczej działalności na Węgrzech, a Polska chce sądzić za zbrodnie w Polsce - nie zachodzi więc przypadek res judicata. Nie może być sprawy stosowania traktatu ekstradycyjnego francusko-polskiego z 1925 r., ponieważ Marta Puretz jest na liście zbrodniarzy wojennych, a w stosunku do nich obowiązują specjalne zobowiązania międzynarodowe ${ }^{94}$. Rok później - dopominając się ekstradycji - Warszawa dostarczyła, jako nowe dowody, kopie i tłumaczenie Trybunału Regionalnego w Budapeszcie z 12 lipca $1951 \mathrm{r}$. Unieważnił on wyrok Trybunału Ludowego w stosunku do Marty Puretz i scedował procedurę karną na sąd polski, „biorąc pod uwagę to, że oskarżona popełniła największą część zbrodni w Polsce"95. Strona francuska nie uwzględniła tego faktu. Zdaniem ministra sprawiedliwości z lektury aktu oskarżenia prokuratury węgierskiej z 30 czerwca 1945 r. i wyroku Trybunału Ludowego z 23 lipca 1945 r. wynikało, iż sąd wziął pod uwagę czyny Marty Puretz na Węgrzech i w Polsce, uniewinniając ją za działania w obu krajach. Tym samym jej sprawa została ostatecznie zamknięta przez Paryż z początkiem $1952 \mathrm{r}^{96}$

W Polsce zaś - po zakończeniu postępowania karnego przez krakowską prokuraturę w 1947 r. ${ }^{97}$ - Urząd Bezpieczeństwa w Krakowie zamknął sprawę

${ }^{90}$ Ibidem, Minister sprawiedliwości do ministra spraw wewnętrznych, Paryż, 28 VI 1948 r.

${ }^{91}$ Ibidem, Ministère de la Justice, Note pour Monsieur le Garde des Sceaux complétant la note du 15 avril 1946 relative à l'extradition de la nomèe Puretz Maria femme Heroz réclamée par la Pologne, Paris 12 VI $1948 \mathrm{r}$.

${ }^{92}$ Ibidem, Le Garde des Sceaux, Ministère de la Justice à Monsieur le Ministre de affaires Etrangères, Paris, 15 VI 1948 r.

${ }^{93}$ Ibidem, Nota ambasady polskiej do francuskiego ministerstwa spraw zagranicznych, $20 \times 1950 \mathrm{r}$.

${ }^{94}$ Ibidem.

${ }^{95}$ AN, 19910593/7, Nota ambasady polskiej do francuskiego ministerstwa spraw zagranicznych, 19 X $1951 \mathrm{r}$.

${ }^{96}$ Ibidem, Le Garde des Sceaux- Ministre de la Justice à Monsieur le Ministre des Affaires Etrangères, Paris, 28 I 1952 r.

${ }^{97}$ Jarkowska-Natkaniec, Wymuszona współpraca..., s. 342. Autorka uważa, że wynikało to z braku obciążających ją dowodów lub niemożności sprowadzenia jej do Polski. Pisze, że 
Marty Puretz w sierpniu 1955 r., rejestrując ją w ewidencji ogólnoinformacyjnej jako „byłą agentkę Gestapo”. W ostatniej notatce wzmiankowano, że Puretz „obecnie przebywa w Afryce Północnej” ${ }^{98}$. Istotnie, w latach 1950-1960 Marta Puretz mieszkała z mężem poza metropolią, nie w Afryce Północnej jednak, lecz we Francuskiej Afryce Zachodniej - w Dakarze, Conakry i ponownie w Dakarze $^{99}$. Po dekolonizacji oboje wrócili do Francji i osiedli w Nicei. Tam też zmarli w swoim apartamencie przy avenue de Fabron 210 - Charles Heroz 28 marca 1989 r., a Marta Heroz, z domu Puretz, 15 stycznia 2000 r. ${ }^{100}$ Mieli syna Alaina, którego daty urodzenia nie udało mi się ustalić ${ }^{101}$.

Tymczasem Stanisław alias Marian Faber - w rzeczywistości Moritz lub Moisze Gerszon - już w 1947 r. zmienił nazwisko i objawił się jako Marian Solski ${ }^{102}$. Marian Faber natomiast został uznany za zmarłego. Solski był zamożny, posiadał cztery kamienice, mieszkał w Krakowie pod adresem „zmarłego” Fabera, czyli przy ul. Starowiślnej 54/6, i prowadził warsztat rzemieślniczy. W latach 19601961 był powiązany z grupą handlarzy towarami zagranicznymi. W $1961 \mathrm{r}$. Marian Solski czynił starania o emigracyjny wyjazd do Izraela ${ }^{103}$. Dalszy jego los jest mi nieznany. Nikczemności Fabera dopełniało to, że mając młodszego brata Stanisława, na Węgrzech podszywał się pod niego i pod jego imieniem prowadził ciemne interesy. Prawdziwy Stanisław - aresztowany przez Niemców i wysłany do obozu - po powrocie do Polski zamieszkał w Krakowie, również przy ul. Starowiślnej 54/6, i w 1950 r. wyemigrował do Izraela z córeczką Marią ${ }^{104}$.

mimo przesłuchania kilku świadków nie odnaleziono dowodów potwierdzających jej współpracę z władzami okupanta - ani proweniencji polskiej, ani niemieckiej.

${ }^{98}$ AIPN Kr, 010/6637, List kierownika Sekcji III Wydziału II E. Marcinkowskiego do zastępcy naczelnika Wydziału II por. K. Kałuży, 29 VIII 1955 r.

${ }^{99}$ Archives départementales, le Département du Doubs, Etats des services de Charles Heroz (matricule 130 classe 1936). Kserokopię dokumentów zawdzięczam uprzejmości Simona Londnera.

${ }^{100}$ Ville de Nice, Acte de décès, copie integrale $N^{\circ} 001598 / 1989$ Charles Heroz; Acte de décès,copie integrale $\mathrm{N}^{\circ}$ 000347/2000 Marthe Puretz. Fotokopię aktu zgonu zawdzięczam Simonowi Londnerowi.

${ }^{101}$ Informację o tym, że Herozom urodził się syn, Simon Londner przekazał e-mailowo 1 I 2018 r., trudno mi traktować ją jednak jako pewnik.

${ }^{102}$ AIPN Kr, 010/7427, Notatka służbowa sporządzona na podstawie akt BDO i materiałów z teczki SPZ, Kraków, 7 VIII 1961 r.; ibidem, Wyciąg z doniesienia TW „Czajka” z 5 IV 1961 r.

${ }^{103}$ Ibidem, Raport o zarejestrowaniu w ewidencji ogólno-informacyjnej Mariana Solskiego, 2 XI $1964 \mathrm{r}$.

${ }^{104}$ AIPN, Referat Informacji i sprawdzeń Oddziału IPN w Krakowie, Materiały po GKBZpNP; ibidem, Materiały po byłych służbach PRL. W cyfrowym archiwum IPN w Kartotece wyjazdów emigracyjnych zapisano: „Stanisław Faber, s. Henryka, ur. 7 V 1912 r., kupiec, Kraków, ul. Bohaterów Stalingradu 54/6, podejrzany przez W.II.S.VI. [Wydział II Sekcję VI] o współpracę z okupantem. Materiały złożono do Arch[iwum] W.Ż., do nr 36666/II/55", zapis z 10 VIII 1955 r.

Informacje uzupełniające uzyskane z IPN po przeprowadzonej kwerendzie: „Żyd polski w Budapeszcie 1943-1945. Z dokumentów z Archiwum w Paryżu wynika, że z jednej strony 
Analiza zeznań Mariana Fabera nastręcza wiele trudu w ustaleniu jego sytuacji rodzinnej. Wynika z nich, że - oprócz innych członków rodziny - miał dwu braci: Pereza, czyli Pawła, który nie przeżył wojny, i właśnie Stanisława. Między Marianem a Stanisławem musiało dojść do rozbratu - pytanie, na jakim tle i kiedy. Świadczy o tym to, że w latach 1956 i 1957, gdy ubiegał się o czasowy wyjazd do Belgii, do siostry Goldy, oraz do Izraela, do drugiej siostry Liby z mężem, nie wymienił jako celu odwiedzin wizyty u brata Stanisława ${ }^{105}$.

\section{Aneks}

W 1947 r. Marta Puretz złożyła wyczerpujące zeznania przed Stałym Trybunałem Wojskowym w Paryżu odnośnie do jej pobytu w Polsce i na Węgrzech. Udokumentowane było dołączonymi spisami osób, które mogły potwierdzić jej działania w Krakowie, a także tych, które ją ukrywały po ucieczce z getta. Dołączyła również listę osób, które ukrywały ją lub pomagały jej na Węgrzech i mogły zaświadczyć o jej postępowaniu.

AN, 19910593/7, Ma déposition faite au $2^{\text {ème }}$ Tribunal Militaire Permanent en Mars 1947, zeznanie Marthe Heroz, Saint Denis, 30 I 1947 r. wraz z załącznikami (w nawiasie, kursywą, zamieszczono tłumaczenie):

\section{Liste de témoins $\mathbf{N}^{\circ} \mathbf{1}$ (Lista świadków nr 1)}

Personnes pouvant témoigner sur mon activité en Pologne (Osoby, które moga zeznawać na temat mojej działalności w Polsce)

1) Ma mère (moja matka) Mme Puretz Rena née (z domu) Kornfeld, 15 rue (ulica) Rozana, chez (przebywająca u) Mlle Maria Feliksiak à Cracovie,

2) Mlle Maria Feliksiak 15 rue (ulica) Rozana à Cracovie

3) Mlle Salomea Feliksik 15 rue (ulica) Rozana à Cracovie

Personnes qui m’ont hébergé et caché en Pologne (Osoby, które udzieliły mi schronienia i ukrywały mnie w Polsce)

1) Mr, Mme Groty-Prokopowicz, 10 rue (ulica) Sereno-Fena à Cracovie

2) Dr Spinarczyk, dentiste, rue (ulica) Lobzowska à Cracovie

3) Dr Chutkowski, dentiste, rue (ulica) Z. Augusta à Cracovie

4) Dr Machauf, medecin à Cracovie

5) Dr Rost Nella, World Jewish Congress, Stockholm, Grev-Maguigatan 11

6) Dr Fendler Gizela, 8 Geralp Roap, London S.W.1.Westminster

7) Mlle Schwaertz à Cracovie

był bratem Mariana Fabera, z drugiej - był równoznaczny z Marianem Faberem. Podobno chciał zbiec do Rumunii. Ożenił się z Martą Puretz w maju 1944 r. na Węgrzech. W zbiorze wykazów spraw o uznanie za zmarłego figuruje Marian Faber".

${ }^{105}$ AIPN Kr, 010/7427, Notatka służbowa sporządzona na podstawie akt BDO materiałów z teczki SPZ, Kraków, 7 VIII 1961 r. 
8) Mlle Hirch Irena et sa famille (i jej rodzina) à Cracovie

9) Mr Appel Daniel ${ }^{106}$ et frère (i brat) à Cracovie

\section{Liste de témoins $\mathbf{N}^{\circ} 2$ (Lista świadków $n r$ 2)}

Personnes prouvant de mon activité en Hongrie: (Osoby, które moga poświadczyć moją działalność na Węgrzech)

1) Schuchner Nandor, Khun utca (ulica) 12 Budapest

2) Findler Otto, Vörösmarty utca (ulica) 57, Budapest

3) Kovacs Lili et famille (wraz z rodzina), Rakoczi ut. (ulica) 47, Budapest

4) Weiss Istvan et (i) György, Zapolia utca (ulica) 22, Budapest

5) Sonntag, Zapolia utca (ulica) 22, Budapest

Personnes qui m'ont caché où aidé en Hongrie: (Osoby, które ukrywały mnie i pomagały mi na Węgrzech)

Mr X... logeur (hotelarz), 59 Vörösmarty utca (ulica), Budapest, témoin de mon arrestation par la police nazie en mars 1944 (świadek mojego aresztowania przez faszystowska policję w marcu $1944 r$.).

Mme Margit Rottenbiller, utca (ulica) ?, employée au café (pracowniczka kawiarni) Muczarnok.

Mr Kovacs Paul, Viola utca (ulica) 18 à Ujpest (Budapest) (actuellement en France) (obecnie we Francji), 1 rue (ulica) de l'Avenir à Saint Denis (Seine).

Mr Kovacs Imre à Kemend (Hongrie) actuellement en France (obecnie we Francji), 13 av. Du Château à Nogent sur Marne.

Mme Kassas, café, Viola utca (ulica) 19.

Mr Ginsbourg Bernard, actuellement (obecnie) à Paris 5 passage des Petites Ecuries.

Mme Beck Karoly, 61a Nagybany ut (ulica), et 47 ou 43 Hajos utca (ulica) à Budapest.

Mme Korany Béla Futo utca (ulica) 41 à Budapest.

Mr, Mme Eve Stapp (dite Warunek) 245 aleja Niepodleglosci, Varsovie, Pologne. Mr Bordato, actuellement (obecnie) à Paris 6 rue (ulica) Robert Oudin, XX⿳亠丷⿵冂丶

\footnotetext{
${ }^{106}$ Nie należy go kojarzyć z rodziną konfidenta Juliana Appela (Jarkowska-Natkaniec, Wymuszona współpraca..., s. 292). Tak naprawdę najważniejszą osobą był Aleksander Förster, niewymieniony na liście, który niejednokrotnie udzielał Marcie schronienia. Na liście ukrywających ją Marta Puretz nie przy wszystkich nazwiskach podała adresy tych osób. Nie można zatem porównać ich z adresami, które podziemie przypisywało Marcie jako miejsca jej działalności agenturalnej. Warto zwrócić uwagę, że wśród tych miejsc były wymieniane najzupełniej „czyste” adresy: Topolowa 1 (tutaj została wysiedlona wraz z rodziną przez Niemców w 1939 r.), Różana 15 (mieszkanie niani i służącej sprzed wojny) i Sereno Fenna 10 (mieszkanie zaprzyjaźnionej rodziny, u której Puretzowie ukryli meble i kosztowności).
} 
Mes domiciles successifs en Hongrie: (Moje następujące po sobie miejsca zamieszkania na Węgrzech)

1) Passarety utca (ulica), Pension Salay sous le nom (pod nazwiskiem) Panecka

2) Vörösmarty utca (ulica) 59

3) Camp d'internement Magdola utca d'où je me suis évadée (Obóz internowania przy ulicy Magdola, skąd uciekłam)

4) Schuchner Nandor Khun utca (ulica) 12

5) Bartalan L. Utca (ulica) 20-22

6) Nagybaya utca (ulica) 61a chez Mme (u pani) Beck, où je suis restée cachée 8 mois sans sortir (gdzie pozostawałam w ukryciu przez 8 miesięcy, nie wychodzq̨c $z$ domu)

7) Viola utca (ulica) à Ujpest chez (u pana) Kovacs

8) Plosz L. Utca (ulica) 12 b où j'ai vécu le siège Budapest (gdzie przeżyłam oblężenie Budapesztu)

9) Camp de rapatriement de Tura (obóz przesiedleńczy w Tura)

\section{BIBLIOGRAFIA}

\section{Źródła archiwalne}

Archives Nationales w Paryżu (AN)

19910593/7, Martha Puretz (Akta dotyczące Marty Puretz i jej męża Charles'a Heroza)

Archiwum Instytutu Pamięci Narodowej w Warszawie (AIPN)

164/4979, Główna Komisja Badania Zbrodni Niemieckich w Polsce. Akta w sprawie 1) Puretz Marta, 2) Brandstätter Stefania

174/29, Okręgowa Komisja Badania Zbrodni Niemieckich w Polsce, Kraków, korespondencja

\section{Archiwum Instytutu Pamięci Narodowej w Krakowie (AIPN Kr)}

010/6637, WUBP, Kraków, protokoły przesłuchań, korespondencja z Prokuraturą Specjalnego Sądu Karnego w Krakowie, Urzędem Bezpieczeństwa w Krakowie, Ministerstwem Bezpieczeństwa Publicznego

010/7427, teczka: Solski Marian (dot. Mariana Fabera)

\section{Literatura przedmiotu}

Bau Józef, Czas zbezczeszczenia. Wspomnienia z czasów drugiej wojny światowej, Tel Awiw: Hamena Anea, 1990.

$W$ trzeciq rocznicę zagłady getta $w$ Krakowie, red. Michał M. Borwicz, Nella Rost, Józef Wulf, Kraków: Centralny Komitet Żydów, 1946.

Bratko Józef, Gestapowcy. Kontrwywiad - konfidenci - konspiratorzy, Kraków: Krakowa Agencja Wydawnicza, 1990.

Chodakiewicz Marek Jan, Agenci i bandy pozorowane na Lubelszczyźnie. Z dziejów okupacji niemieckiej w Janowskiem, „Radzyński Rocznik Humanistyczny” 2002, nr 2.

Czuma Mieczysław, Mazan Leszek, Tate, jedziemy do Krakowa!, Kraków: Anabasis, 2015.

Dalej jest noc. Losy Żydów w wybranych powiatach okupowanej Polski, t. 1-2, red. Barbara Engelking, Jan Grabowski, Warszawa: Stowarzyszenie Centrum Badań nad Zagładą Żydów, 2018. 
Grądzka-Rejak Martyna, Kobieta żydowska w okupowanym Krakowie (1939-1945), Kraków: Wysoki Zamek, 2016.

Hall Claire M., An Army of Spies? The Gestapo Spy Network 1933-45, „Journal of Contemporary History" 2009, t. 44, nr 2.

Hubbard-Hall, Claire M., "A Game of Cat-and-Mouse". The Gestapo Spy Network in Tomaschow Mazowiecki, Poland 1939-45 [w:] War in a Twilight World: Partisan and Anti-Partisan Warfare in Eastern Europe, 1939-45, red. Juliette Pattinson, Ben Shepherd, London: Palgrave Macmillan, 2010.

Jarkowska-Natkaniec Alicja, Wymuszona współpraca czy zdrada. Wokół przypadków kolaboracji Żydów w okupowanym Krakowie, Kraków: Universitas, 2018.

Mędykowski Witold, Przeciw swoim. Wzorce kolaboracji żydowskiej w Krakowie i okolicy, „Zagłada Żydów. Studia i Materiały” 2006, nr 2.

Pankiewicz Tadeusz, Apteka w getcie krakowskim, Kraków: Wydawnictwo Literackie, 2015.

Rympel Manuel, Słowo o Żydach krakowskich w okresie międzywojennym (1918-1939), [w:] Kopiec wspomnień, Kraków: Wydawnictwo Literackie, 1964.

Scharf Rafael, Co mnie i Tobie Polsko... Eseje bez uprzedzeń, Kraków: Fundacja Judaica „Universitas”, 1996.

Tausendfreund Doris, Erzwungener Verrat jüdische „Greifer” im Dienste der Gestapo 1943-1945 (Documente, Tekste, Materialien), Berlin: Metropol, 2005.

\section{Netografia}

https://www.ancestry.com/search/collections/2484/ (Kraków, Poland, ID Card Applications for Jews During WWII, 1940-1941 [USHMM], dane personalne członków rodziny Puretz 1939/1940)

https://www.ushmm.org/online/hsv/person_view.php?PersonId=6096356 (Holocaust Survivors and Victims Database, adres Marty Puretz 1939/1940) https://www. ushmm.org/online/hsv/person_view.php?PersonId=6096362 (Holocaust Survivors and Victims Database, adres Reny Puretz 1939/1940)

https://www.ushmm.org/online/hsv/person_view.php?PersonId=6096358\&ReferPersonId=6096357 (Rena Puretz)

https://www.ushmm.org/online/hsv/person_view.php?PersonId=6096363\&ReferPersonId=6096364 (Rosa Puretz)

https://www.ushmm.org/online/hsv/person_view.php?PersonId=6096350 (Marta Puretz) 
